\title{
Partitioning forest carbon fluxes with overstory and understory eddy-covariance measurements: A synthesis based on FLUXNET data
}

\author{
Laurent Misson $^{\text {a,* }}$, D.D. Baldocchi ${ }^{\text {b }}$, T.A. Black ${ }^{\text {c }}$, P.D. Blanken ${ }^{\text {d }}$, Y. Brunet ${ }^{\mathrm{e}}$, \\ J. Curiel Yuste ${ }^{\mathrm{b}}$, J.R. Dorsey ${ }^{\mathrm{b}}$, M. Falk ${ }^{\mathrm{f}}$, A. Granier ${ }^{\mathrm{g}}$, M.R. Irvine ${ }^{\mathrm{e}}$, N. Jarosz ${ }^{\mathrm{e}}$, \\ E. Lamaud $^{\mathrm{e}}$, S. Launiainen ${ }^{\mathrm{h}}$, B.E. Law ${ }^{\mathrm{i}}$, B. Longdoz ${ }^{\mathrm{g}}$, D. Loustau ${ }^{\mathrm{e}}$, M. McKay ${ }^{\mathrm{b}}$, \\ K.T. Paw $\mathrm{U}^{\mathrm{f}}$, T. Vesala ${ }^{\mathrm{h}}$, D. Vickers ${ }^{\mathrm{i}}$, K.B. Wilson ${ }^{\mathrm{j}}$, A.H. Goldstein ${ }^{\mathrm{b}}$ \\ ${ }^{\text {a } C E F E-C N R S, ~} 1919$ route de Mende, 34293 Montpellier Cedex 5, France \\ ${ }^{\mathrm{b}}$ ESPM Department, 137 Mulford Hall, University of California, Berkeley, CA 94720-3110, United States \\ ${ }^{\mathrm{c}}$ Faculty of Land and Food Systems, 135-2357 Main Mall, University of British Columbia, Vancouver, BC, Canada V6T 1Z4 \\ ${ }^{\mathrm{d}}$ Department of Geography and Environmental Studies, University of Colorado at Boulder, 260 UCB, \\ Boulder, CO 80501-0260, United States \\ ${ }^{\mathrm{e}}$ INRA-EPHYSE, BP 81, 71, rue Edouard Bourleaux, 33883 Villenave d'Ornon Cedex, France \\ ${ }^{\mathrm{f}}$ Atmospheric Science, Biomicrometeorology Group, University of California, Davis, CA 95616, United States \\ ${ }^{\mathrm{g}}$ UMR Ecologie et Ecophysiologie Forestières, Centre INRA de Nancy, Route de l'Arboretum, 54280 Champenoux, France \\ ${ }^{\mathrm{h}}$ Department of Physical Sciences, P.O. Box 64, FIN 00014, University of Helsinki, Finland \\ ${ }^{\mathrm{i}}$ College of Forestry, 328 Richardson Hall, Oregon State University, Corvallis, OR 97331, United States \\ ${ }^{\mathrm{j}}$ Atmospheric Turbulence and Diffusion Division, NOAA, Oak Ridge, TN, United States
}

\begin{abstract}
Forests are complex ecosystems characterized by several distinctive vertical layers with different functional properties. Measurements of $\mathrm{CO}_{2}$ fluxes by the eddy-covariance method at different heights can be used to separate sources and sinks in these layers. We used meteorological and eddy-covariance flux data gathered at 10 sites in the FLUXNET network across a wide range of forest type, structure and climate. We showed that eddy-covariance flux measurements made in the understory are problematic at night in open forests because of the build up of a strong inversion layer, but are more reliable during the day. Denser forests have higher turbulence at night in the understory because the inversion is weaker. However, the flux footprint above and below canopy is less similar than in more open forests, partly because wind direction is more deflected while entering the canopy. We showed that gross primary productivity (GPP) of the understory can reach $39 \%$ of the total canopy GPP, with an average of $14 \%$ across the studied sites. Both understory leaf area index (LAI) and light penetration through the canopy are important for understory GPP. We found that understory respiration contributed an average of $55 \%$ to ecosystem respiration, with a range of $32-79 \%$. Understory in deciduous forests $(62 \%)$ had higher contributions to ecosystem respiration than in evergreen forests $(49 \%)$. Boreal and temperate forests had a mean understory respiration contribution of $61 \%$, while semi-arid forests showed lower values $(44 \%)$. The normalized understory respiration fluxes at $20{ }^{\circ} \mathrm{C}$ were negatively related to soil temperature, when differences in soil moisture across sites are taken into account. We showed evidence that drought limited the
\end{abstract}

\footnotetext{
* Corresponding author. Tel.: +334676132 93; fax: +33467412138 .

E-mail address: laurent.misson@cefe.cnrs.fr (L. Misson).
} 
efficiency of microbial metabolic activity. Understory respiration fluxes were positively correlated with gross ecosystem primary productivity.

(C) 2007 Elsevier B.V. All rights reserved.

Keywords: Net ecosystem exchange; Photosynthesis; Respiration; Forest floor; Evergreen; Deciduous

\section{Introduction}

Forests influence atmospheric composition and climate significantly because they act as important sources and sinks of trace gases and energy, both locally and regionally. In order to predict how they will respond to climate change, we need to better understand how fluxes of $\mathrm{CO}_{2}$ between forests and the atmosphere respond to their contemporary climate. This information is crucial to quantify and predict the vegetation feedback on the climate system (Fung et al., 2005). Forests are complex ecosystems, usually characterized by great variability in structure and composition, both vertically and horizontally. In particular, they are characterized by several distinctive layers with very different functional properties, both in the overstory and the understory. Each of these layers contributes differently to the $\mathrm{CO}_{2}$ exchange with the atmosphere. Canopy photosynthesis mostly occurs in the overstory and is typically a function of leaf area index, photosynthetic capacity, light, temperature and moisture. Ecosystem respiration is generally dominated by soil sources, and responds to temperature, soil moisture and substrate availability. Thus, the vertical location of these fluxes in the canopy and their environmental controls differ and are non-linear (Baldocchi et al., 2000; Blanken et al., 1998; Constantin et al., 1999; Launiainen et al., 2005). Measurements of $\mathrm{CO}_{2}$ and energy fluxes at different heights in a forest can be used to separate these different sources and sinks in order to more fully understand, quantify and predict the influence of vegetation on atmospheric composition and climate. Measurements of stable isotopes have been a popular means of attempting to partition fluxes, but they are inferential and until the recent advent of the Tunable Diode Laser system they have been measured episodically. In contrast, using understory and overstory eddy-covariance systems provides a means of teasing out differences in fluxes attributed to the vegetation and soil, given adequate conditions and circumstances.

Twenty years ago, the eddy-covariance method emerged as a key method for measuring trace gas and energy exchange between whole ecosystems and the atmosphere (Baldocchi, 2003). In recent years, several papers have also reported eddy-covariance flux mea- surements in the understory, with the objectives: (1) to test and validate the applicability of this technique for measuring gas and energy fluxes at the forest floor (Baldocchi et al., 2000; Baldocchi and Meyers, 1991; Blanken et al., 1998; Constantin et al., 1999; Denmead and Bradley, 1985; Lamaud et al., 2001; Launiainen et al., 2005; Lee and Black, 1993), (2) to assess the spatial variability of subcanopy fluxes (Wilson and Meyers, 2001; Yang et al., 1999), (3) to investigate the factors controlling these fluxes (Baldocchi et al., 2000; Baldocchi and Vogel, 1996; Baldocchi et al., 1997a,b; Black et al., 1996; Blanken et al., 1997; Falk et al., 2005; Kelliher et al., 1999; Launiainen et al., 2005; Law et al., 1999; Wilson et al., 2000), (4) to partition above canopy fluxes between their overstory and understory components (Baldocchi and Vogel, 1996; Baldocchi et al., 1997b; Black et al., 1996; Constantin et al., 1999; Falk et al., 2005; Kelliher et al., 1999; Launiainen et al., 2005; Law et al., 2001a; Scott et al., 2003; Wilson et al., 2000) and (5) to compare forest floor eddy-covariance estimates of respiration with soil chamber estimates (Black et al., 1996; Janssens et al., 2001a; Kelliher et al., 1999; Launiainen et al., 2005; Law et al., 1999; Subke and Tenhunen, 2004).

In this context, we need now to identify and compare the factors controlling the carbon flux partitioning between the overstory and understory across different climates and forest types. Caution is required when using the eddy-covariance method in a forest understory because the underlying assumptions for this method are not expected to be generally valid in the conditions prevailing there: low wind speed, strong heterogeneity and intermittent turbulence (Baldocchi et al., 2000; Blanken et al., 1998; Constantin et al., 1999; Launiainen et al., 2005). However, after a thorough validation of turbulent flux measurement, it has been shown repeatedly that the method is indeed capable of measuring fluxes at the forest floor (Baldocchi et al., 2000; Black et al., 1996; Blanken et al., 1998; Constantin et al., 1999; Janssens et al., 2000; Lamaud et al., 2001; Launiainen et al., 2005). This is especially true when studying ecosystem physiology, which generally does not require the same degree of accuracy as turbulence studies (Lamaud et al., 2001). Information on how canopy structure influences canopy micrometeorology is still needed to interpret 
above canopy and subcanopy eddy-covariance fluxes across a wide range of forest type, structure and climate. Temperature, light, wind and turbulence stratification through the canopy need to be described for different forests because they influence the applicability of the eddy-covariance method.

The first eddy-covariance measurements in a forest understory were conducted in the 1980s (Denmead and Bradley, 1985; Baldocchi et al., 1986). Since then, an extensive number of similar studies have been conducted across many forest types integrated into FLUXNET, a worldwide network of stations measuring fluxes by the eddy-covariance method (Baldocchi et al., 2001). The FLUXNET dataset provides a great opportunity to examine the micrometeorology and fluxes at two levels in the canopy, across a wide range of forest ecosystems and climates. In this study, we used meteorological and eddycovariance flux data gathered at 10 sites in the FLUXNET network, chosen to cover a large range of canopy closure, functional types and climates (Tables 1 and 2). Our first objective was to compare the micrometeorology and the fluxes of $\mathrm{CO}_{2}$ measured by the eddy-covariance method, above and below the main canopy of these different forests. Our second objective was to identify the factors controlling the flux partitioning between the overstory and understory across different climates and forest types, with a focus on separating photosynthetic assimilation sinks and respiration sources. Specific questions addressed include: (1) what are the effects of the overstory canopy density on the understory micrometeorology, and on the coupling between overstory and understory conditions? (2) What are the effects of the overstory canopy density on $\mathrm{CO}_{2}$ flux partitioning between understory and overstory? (3) What environmental and biological factors control understory $\mathrm{CO}_{2}$ fluxes across different climates and forest types, both at night and during the day? We hypothesize that the overstory leaf area index is the main factor influencing change in meteorology and flux partitioning between overstory and understory across forest types and climates.

\section{Material and methods}

Symbols, definitions and units used in this paper are given in Appendix A. A comprehensive review of the literature was performed to gather information on sites where eddy-covariance has been used to measure $\mathrm{CO}_{2}$ and energy fluxes, both above and below the main forest canopy. Based on this review, we selected sites in evergreen and deciduous forests across a large range of climates and forest types (Tables 1 and 2). The sites are located in boreal, temperate and arid/semi-arid climates. They have good data quality control and validation procedures, long time series and relatively complete meteorological and ancillary data.

In general, the available data include: (1) half-hourly meteorological data both above and below the main canopy, (2) half-hourly $\mathrm{CO}_{2}$, water and energy eddycovariance fluxes at these two levels and (3) ancillary data such as species composition, overstory and understory heights and leaf area indexes (LAI). Not all these data were available for all the sites, so different analyses and figures do not always include the same sites. The methods used for flux measurements follow the FLUXNET methodology described in Aubinet et al. (2000) and Baldocchi et al. (2001). Specifics on methodology used for each site, including data quality control and validation, can be found in individual papers referenced in Table 1 .

The storage term was taken into account for computing the $\mathrm{CO}_{2}$ fluxes above the canopy, but not below the canopy because it is generally assumed that it is negligible at this level. This might not always be the case, especially when the height of the subcanopy eddycovariance system was high (Table 2). The meteorological variables presented in this paper were measured at similar height as eddy-covariance fluxes, both above and below the canopy (Table 2). For most of the sites, raw eddy-covariance data were not readily available. Therefore, detailed turbulence statistics and spectral analysis were not performed, but this information can be found in many of the individual papers cited on Table 1 and referenced throughout this manuscript. In this paper, we used 1 year of data at each site and concentrated on the summer period because that was when most data were available across the different sites. This season corresponds to the period when the main canopy of both evergreen and deciduous forests was fully foliated, and during which we observed active and steady $\mathrm{CO}_{2}$ sequestration (see Appendix B). Data at an oak savanna site were separated into two different periods (To1 and To2) due to its Mediterranean climate. The first period, from day 90 to 150 (To1), was characterized by mild temperature, high soil moisture and the presence of both active oaks in the overstory and an active herbaceous understory. The second period, from day 150 to 250 (To2), was characterized by very high temperature, very low soil moisture and the presence of active oaks in the overstory, while the herbaceous understory was dead. This paper focuses on examining the meteorology and the $\mathrm{CO}_{2}$ fluxes, while another paper in preparation deals with latent and sensible heat fluxes and the energy balance. 
Table 1

Selected characteristics of the sites, part 1

\begin{tabular}{|c|c|c|c|c|c|c|c|}
\hline Type & Climate & Site & Abbreviation & State, country & $\begin{array}{l}\text { Main species } \\
\text { overstory }\end{array}$ & $\begin{array}{l}\text { Main species } \\
\text { understory }\end{array}$ & Main reference \\
\hline \multirow[t]{6}{*}{ Evergreen } & Boreal & Jackpine & $\mathrm{Jac}$ & Saskatchewan, CA & Jack pine & Green alder & Baldocchi and Vogel (1996) \\
\hline & Boreal & Hyytiala & Hyy & Finland & Scots pine & Dwarf shrubs & Launiainen et al. (2005) \\
\hline & Temperate & Wind River & Wri & Washington, USA & Douglas fir & Vine maple & Falk et al. (2005) \\
\hline & Temperate & Le Bray & Leb & France & Maritime pine & Purple-moor grass & Lamaud et al. (2001) \\
\hline & Semi-arid & Metolius & Met & Oregon, USA & Ponderosa pine & Antelope bitterbrush & Law et al. (1999) \\
\hline & Semi-arid & Blodgett & Blo & California, USA & Ponderosa pine & Whiteleaf manzanita & Misson et al. (2006a) \\
\hline \multirow[t]{4}{*}{ Deciduous } & Boreal & Aspen & Asp & Saskatchewan, CA & Aspen & Hazelnut & Black et al. (1996) \\
\hline & Temperate & Hesse & Hes & France & Beech & White-wood rush & Granier et al. (2000) \\
\hline & Temperate & Walker Branch & Wbr & Tennessee, USA & White oak & Hickory and Maple & Wilson et al. (2000) \\
\hline & Arid & Tonzi & To1 and To2 & California, USA & Blue oak & Bromus sp. & Baldocchi et al. (2004) \\
\hline
\end{tabular}

Attenuation of photosynthetic active radiation (PAR) in the canopy was calculated as

$100-\frac{\mathrm{PAR}_{\mathrm{B}}}{\mathrm{PAR}_{\mathrm{A}}} \times 100(\%)$

where $\mathrm{PAR}_{\mathrm{B}}$ is radiation below the main canopy and $\mathrm{PAR}_{\mathrm{A}}$ is radiation above the main canopy. We calculated $u^{*}$ attenuation between the top and the bottom of the canopy by

$100-\frac{u_{\mathrm{B}}^{*}}{u_{\mathrm{A}}^{*}} \times 100(\%)$

where $u_{\mathrm{A}}^{*}$ is measured above the main canopy and $u_{\mathrm{B}}^{*}$ is measured similarly to $u_{\mathrm{A}}^{*}$ but below the main canopy. To investigate the coupling between turbulence above and below the canopy, we calculated the linear regression:

$u_{\mathrm{B}}^{*}=a+b u_{\mathrm{A}}^{*}$

where $b$ is a coupling coefficient.
The friction velocities and PAR measurements were also used to determine exponential extinction coefficients following Inoue (1963), Cionco (1965, 1972), Thom (1975) and Raupach and Thom (1981), using the following equations:

$u^{*}(z)=u^{*}\left(h_{\mathrm{c}}\right) \mathrm{e}^{\left(-\gamma \mathrm{L}_{\mathrm{a} i}\right)}$

$\gamma_{1}=\gamma h_{\mathrm{c}}$

$u^{*}(z)=u^{*}\left(h_{\mathrm{c}}\right) \mathrm{e}^{\left(-\alpha\left(1-z / h_{\mathrm{c}}\right)\right)}$

$\operatorname{PAR}(z)=\operatorname{PAR}\left(h_{\mathrm{c}}\right) \mathrm{e}^{\left(-\gamma_{\mathrm{P}} \mathrm{LAI}\right)}$

where $h_{\mathrm{c}}$ is the canopy height, $z$ the height of measurement, $\gamma$ an exponential extinction coefficient for the canopy with respect to canopy leaf area index LAI, $\gamma_{1}$ a length scale for the canopy associated with $\gamma, \alpha$ an

Table 2

Selected characteristics of the sites, part 2

\begin{tabular}{|c|c|c|c|c|c|c|c|c|c|c|}
\hline Site & $\begin{array}{l}\text { Elevation } \\
\text { (masl) }\end{array}$ & $\begin{array}{l}\text { Age } \\
\text { (years) }\end{array}$ & $\begin{array}{l}\text { Mean } \\
\text { diameter at } \\
1.3 \mathrm{~m}(\mathrm{~cm})\end{array}$ & $\begin{array}{l}\text { Mean } \\
\text { height } \\
\text { (m) }\end{array}$ & $\begin{array}{l}\mathrm{LAI}_{\mathrm{A}} \\
\text { overstory } \\
\left(\mathrm{m}^{2} \mathrm{~m}^{-2}\right)\end{array}$ & $\begin{array}{l}\mathrm{LAI}_{\mathrm{B}} \\
\text { understory } \\
\left(\mathrm{m}^{2} \mathrm{~m}^{-2}\right)\end{array}$ & $\begin{array}{l}\text { Mean } \\
\text { annual air } \\
\text { temp. }\left(C^{\circ}\right)\end{array}$ & $\begin{array}{l}\text { Mean annual } \\
\text { precipitation } \\
(\mathrm{mm})\end{array}$ & $\begin{array}{l}\text { Height of } \\
\text { subcanopy EC } \\
\text { system (m) }\end{array}$ & Slope $(\%)$ \\
\hline Jackpine & 579 & 80 & 11.7 & 13.5 & 2.1 & $<0.1$ & 0.4 & 467 & 1.8 & $2-5$ \\
\hline Hyytiala & 181 & 41 & 16.2 & 14.5 & 2.3 & $<0.1$ & 3.8 & 709 & 3.0 & $<5$ \\
\hline Wind River & 371 & 500 & 38 & 67 & 9.0 & 1.7 & 8.7 & 2467 & 2.5 & $5-10$ \\
\hline Le Bray & 60 & 32 & 30 & 20 & 2.7 & 1.1 & 13.6 & 900 & 6.0 & 0.2 \\
\hline Metolius & 1310 & 57 & 29 & 20 & 3.0 & 0.16 & 7.65 & 577 & 2.0 & $2-6$ \\
\hline Blodgett & 1315 & 13 & 12 & 4.7 & 1.8 & 0.7 & 9 & 1290 & 1.2 & $2-15$ \\
\hline Aspen & 600 & 91 & 20 & 21.5 & 2.3 & 3.2 & 0.4 & 467 & 4.0 & $<5$ \\
\hline Hesse & 300 & 36 & 8 & 16 & 7.5 & $<0.1$ & 9.2 & 820 & 2.0 & $<5$ \\
\hline Walker Branch & 365 & 55 & 22 & 26 & 6.0 & 0.3 & 13.9 & 1350 & 2.0 & $5-15$ \\
\hline Tonzi & 177 & 100 & 19.9 & 7.1 & 1.0 & $0.7-0$ & 16.6 & 559 & 1.8 & $<5$ \\
\hline
\end{tabular}

$\mathrm{LAI}_{\mathrm{A}}$, Leaf area index of the overstory and $\mathrm{LAI}_{\mathrm{B}}$, leaf area index of the understory. 
exponential coefficient traditionally used to relate mean wind speed within the canopy to wind speed above, which works out to the same general equation for $u^{*}$ (Smith et al., 1972; Raupach, 1987) and $\gamma_{P}$ is an exponential coefficient for the extinction of PAR in a canopy. Canopy drag coefficients $\left(c_{\mathrm{d}}\right)$ were also determined using the equation:

$c_{\mathrm{d}}=\frac{\alpha\left(2 \ell^{2}\right)^{1 / 3}}{L_{\mathrm{a} i} h_{\mathrm{c}}{ }^{1 / 3}}$

where $\ell$ is a dimensionless within-canopy parameter defined as by Meyers and Paw U (1986) assumed to be 0.060 , used in determining the characteristic canopy length scale for turbulence.

The overstory eddy-covariance system directly measures the net fluxes above the canopy $\left(F_{\mathrm{CO}_{2}, \mathrm{~A}}\right)$, which is also the difference between whole canopy photosynthesis $\left(\mathrm{GPP}_{\mathrm{A}}\right)$ and whole ecosystem respiration $\left(R_{\mathrm{A}}\right)$ :

$F_{\mathrm{CO}_{2}, \mathrm{~A}}=R_{\mathrm{A}}-\mathrm{GPP}_{\mathrm{A}}$

The adopted sign convention is with respect to the atmosphere, so losses of $\mathrm{CO}_{2}$ from the atmosphere (negative flux) reflect gains by the ecosystem. The understory eddy-covariance system directly measures the net fluxes below the canopy $\left(F_{\mathrm{CO}_{2}, \mathrm{~B}}\right)$, which is also the difference between photosynthesis from understory vegetation $\left(\mathrm{GPP}_{\mathrm{B}}\right)$ and the sum of respiration from the understory vegetation and the soil $\left(R_{\mathrm{B}}\right)$ :

$F_{\mathrm{CO}_{2}, \mathrm{~B}}=R_{\mathrm{B}}-\mathrm{GPP}_{\mathrm{B}}$

At night, there is no photosynthesis, so

$F_{\mathrm{CO}_{2}, \mathrm{~A}}=R_{\mathrm{A}}$

and

$F_{\mathrm{CO}_{2}, \mathrm{~B}}=R_{\mathrm{B}}$

These net nighttime fluxes were used to parameterize a $Q_{10}$ relationship between respiration at both levels and soil temperature $\left(T_{\mathrm{s}}\right)$ at 5 or $10 \mathrm{~cm}$, depending on the site. We selected only well ventilated nights based on a $u^{*}$ criteria for both levels (see Appendices C and D). These relationships were used during the day to estimate photosynthesis of the whole canopy and of the understory vegetation as

$\mathrm{GPP}_{\mathrm{A} \text { or B }}=R_{\mathrm{A} \text { or B }}\left(T_{\mathrm{s}}\right)-F_{\mathrm{CO}_{2}, \mathrm{~A} \text { or B }}$

Mean nighttime summer fluxes were calculated using a $u$ threshold determined for both above canopy fluxes and below canopy fluxes using a methodology described in Aubinet et al. (2000) (see Appendix E) Forest floor contribution to the $\mathrm{CO}_{2}$ flux above the canopy was calculated in $\%$ as

$100-\frac{F_{\mathrm{CO}_{2}, \mathrm{~B}}}{F_{\mathrm{CO}_{2}, \mathrm{~A}}} \times 100$,

where $F_{\mathrm{CO}_{2}, \mathrm{~A}}$ is the flux of $\mathrm{CO}_{2}$ at the top of the canopy and $F_{\mathrm{CO}_{2}, \mathrm{~B}}$ is the flux at the forest floor.

The calculation of nighttime understory contribution to the above canopy fluxes (see Eq. (14)) should be taken with caution, considering that $\mathrm{CO}_{2}$ emitted by the soil could be stored in the canopy during the night and assimilated by leaves during the early hours of the day, without passing the level of the above canopy eddycovariance system. The probability of gas transport out of canopy can be calculated by:

$p=\frac{F_{\mathrm{EC}, \mathrm{A}}}{\left(F_{\mathrm{EC}, \mathrm{A}}+F_{\mathrm{s}}\right)}$

where $F_{\mathrm{EC}, \mathrm{A}}$ is the eddy-covariance flux measured above the canopy and $F_{\mathrm{s}}$ is the storage flux. This formula can be used only if the advective $\mathrm{CO}_{2}$ flux is zero or negligible, which should be the case in flat terrain with high turbulence conditions. We calculated this probability $p$ for different turbulence conditions, with $u^{*}$ threshold at top of the canopy ranging from $>0.3$ to $>0.6 \mathrm{~m} \mathrm{~s}^{-1}$, and investigate the relationship between $p$ and LAI across the different sites.

\section{Results}

\subsection{Micrometeorology}

Fig. 1a shows that attenuation of PAR increased with $\mathrm{LAI}_{\mathrm{A}}$ of the main canopy. The shape of the relationship is concave with an asymptote at $\sim 100 \%$ and has been fitted with the exponential equation presented in Fig. 1a, without taking into account the effect of leaf angle or clumping $\left(r^{2}=0.99, p<0.01\right)$. Denser canopies had higher PAR attenuation and lower PAR understory, and we expected that this would influence negatively the development of the understory vegetation. However, denser canopies did not necessarily have lower understory vegetation $\left(\mathrm{LAI}_{\mathrm{B}}\right)$, and vice versa, as shown in Table 2: sites such as Wind River had a $\mathrm{LAI}_{\mathrm{B}}$ of $1.7 \mathrm{~m}^{2} \mathrm{~m}^{-2}$ at the forest floor even as its main canopy $\mathrm{LAI}_{\mathrm{A}}$ was $9 \mathrm{~m}^{2} \mathrm{~m}^{-2}$, while drier sites such as Blodgett and Tonzi had both lower overstory $\mathrm{LAI}_{\mathrm{A}}$ and understory $\mathrm{LAI}_{\mathrm{B}}$. Obviously, differences in climate 

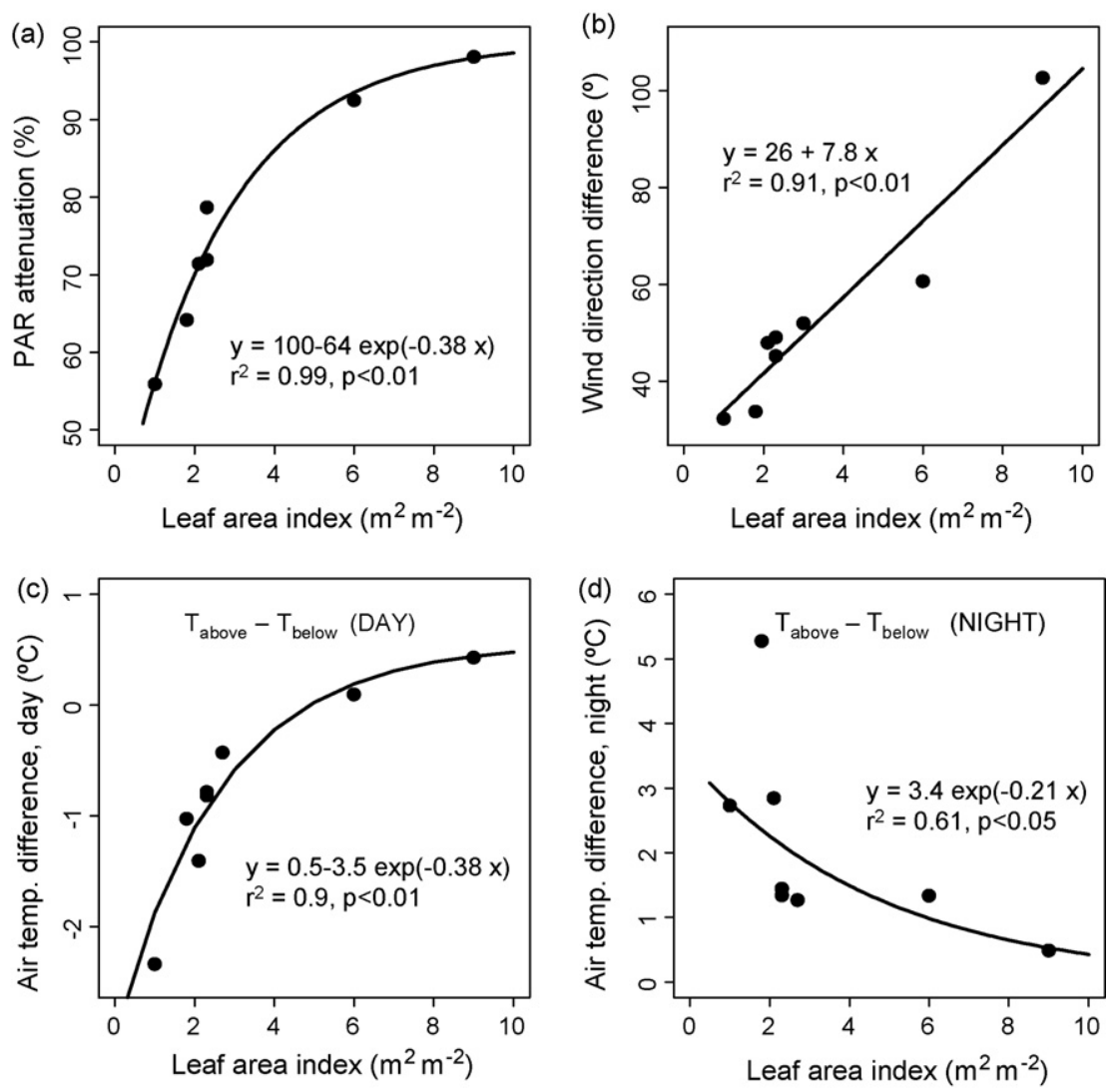

Fig. 1. Mean summer meteorological variables above and below main canopies with different leaf area indexes.

influenced variation in leaf area index between sites, affecting both the overstory and understory.

The difference in wind direction between the overstory $\left(W_{\mathrm{D}, \mathrm{A}}\right)$ and the understory $\left(W_{\mathrm{D}, \mathrm{B}}\right)$ eddycovariance systems has been calculated for the summer, when all sites were fully foliated. Wind direction differences presented in Fig. 1b reflect how much the wind direction understory deviate from overstory in absolute value, either to the left or to the right. Difference in wind direction between the two levels increased linearly with leaf area index above the subcanopy system $\left(\mathrm{LAI}_{\mathrm{A}}\right)$ (Fig. $1 \mathrm{~b}$, with $r^{2}=0.91$ and $p<0.01$ ). Daytime and nighttime differences in above versus below canopy wind direction were both related to leaf area index in a similar fashion, however, the difference was generally higher at night $\left(+12^{\circ}\right.$ on average). On average across the sites, $60 \%$ of the halfhour wind direction measurements understory deviated to the left when compared with overstory; but with a large range between the sites (33-75\%) (not shown).

Air temperature measurements using aspirated thermometers were used to calculate the difference in air temperature between the two levels $\left(T_{\mathrm{A}}-T_{\mathrm{B}}\right)$, during summer day and night. Daytime temperature was generally higher below the main canopy than above, and this difference was inversely correlated to $\mathrm{LAI}_{\mathrm{A}}$ $\left(r^{2}=0.9, p<0.01\right)$ (Fig. 1c). Nighttime temperature was higher above the canopy, with stronger inversions in open canopies $\left(r^{2}=0.61, p<0.05\right)$ (Fig. 1d). We tried to relate these temperature differences with other factors varying across the sites: wind speed, $u^{*}$, net radiation, latent heat flux and sensible heat flux, but no significant relationships were found during either day or night. As a consequence of differences in air temperature stratification across sites, the mean diurnal air temperature difference at the forest floor was higher for open canopies than for more closed canopies $\left(r^{2}=0.57, p<0.05\right.$, not shown).

Fig. 2a shows that during the day, attenuation of $u^{*}$ in the canopy was significantly higher in closed canopies than in more open canopies $\left(r^{2}=0.64, p<0.01\right)$. During the night, this relationship did not hold $\left(r^{2}=0.00, p>0.05\right)$, and average $u^{*}$ attenuation across the sites was $77 \%$ ( \pm 3.8 standard deviation) (Fig. 2a). Sites with lower $\mathrm{LAI}_{\mathrm{A}}$ had a $u^{*}$ attenuation at night generally increasing in comparison to values calculated 

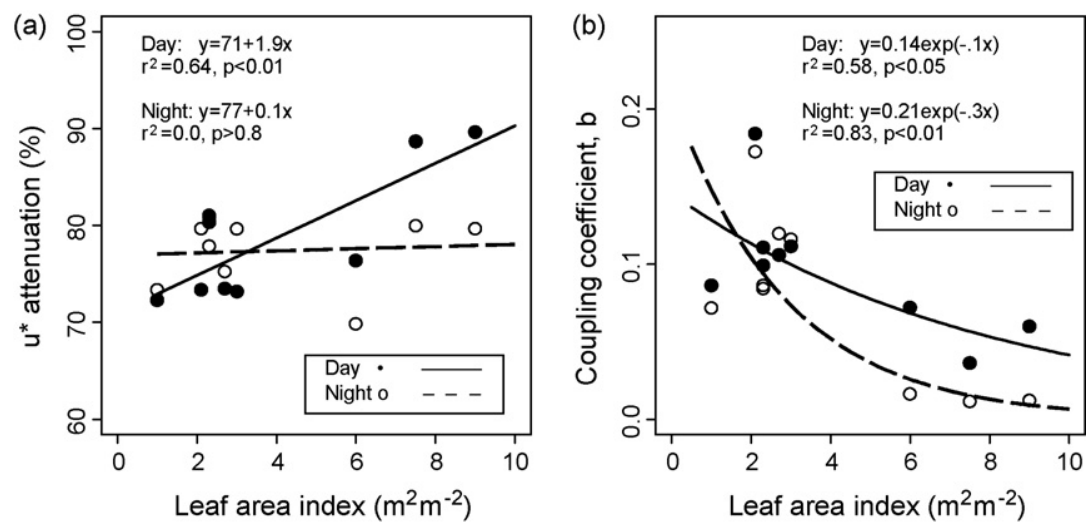

Fig. 2. (a) Mean $u^{*}$ attenuation and (b) coupling coefficient $b$ (from fitting $u_{\mathrm{B}}^{*}=a+b u_{\mathrm{A}}^{*}$ ) as a function of leaf area index, for daytime and nighttime summer conditions.

during the day (Fig. 2a). Sites with higher $\mathrm{LAI}_{\mathrm{A}}$ had nighttime $u^{*}$ attenuation generally decreasing in comparison to daytime values (Fig. 2a). These differences were probably due to variations in air temperature stratification across sites (see Fig. 1c and d). The coupling coefficient $b$ (see Eq. (3)) was significantly related to $\mathrm{LAI}_{\mathrm{A}}$, both during the day and night, meaning that closed canopy promoted different turbulence regimes at the top and the bottom of the canopy (Fig. 2b). However, this relationship was stronger during the night, with almost a total decoupling between turbulence conditions above and below closed canopies ( $b \rightarrow 0$ when $\mathrm{LAI}_{\mathrm{A}}>6$; Fig. $2 \mathrm{~b}$ ).

The traditional micrometeorological canopy parameters for $u^{*}$ do not show a clear diurnal pattern (Table 3). The drag coefficients are inversely proportional to the leaf area index (Table 3). The canopy scale ranged from 3 to $21 \mathrm{~m}$ and the radiation extinction coefficients ranged from 0.43 to 0.82 (Table 3 ).

\subsection{Daytime $\mathrm{CO}_{2}$ fluxes}

Mean daytime net $\mathrm{CO}_{2}$ fluxes above the canopy were all negative (net uptake) during summer. Net fluxes below the canopy were positive and dominated by respiration at 8 of the 11 sites (maximum: $4.5 \mu \mathrm{mol} \mathrm{m}^{-2} \mathrm{~s}^{-1}$ ), while the remaining were negative and dominated by photosynthesis (minimum: $-2.1 \mu \mathrm{mol} \mathrm{m} \mathrm{m}^{-2} \mathrm{~s}^{-1}$ ) (Fig. 3a). The understory contribution to the net $\mathrm{CO}_{2}$ flux above the canopy varied between $36 \%$ at Blodgett (dominated by photosynthesis) and $-54 \%$ at the Jackpine site (dominated by respiration) (Fig. 3b). Almost all the sites showed positive $\mathrm{GPP}_{\mathrm{B}}$ in the understory, except for Walker Branch (Wbr) and Tonzi2 (To2) where $\mathrm{GPP}_{\mathrm{B}}$ was equal to 0 (Fig. 4a). While leaf area index of the understory at To 2 was zero, Wbr reported $0.3 \mathrm{~m}^{2} \mathrm{~m}^{-2}$ (Table 2). The maximum understory $\mathrm{GPP}_{\mathrm{B}}$ of all sites was calculated for Tonzi1 (To1) with $4.7 \mu \mathrm{mol} \mathrm{m}^{-2} \mathrm{~s}^{-1}$ (Fig. 4a). This site was characterized by mild

Table 3

Results for exponential form equations (Eqs. (4)-(8))

\begin{tabular}{|c|c|c|c|c|c|c|c|}
\hline Site & $c_{\mathrm{d}}$ (daytime) & $c_{\mathrm{d}}$ (nighttime) & $\begin{array}{l}\gamma \text { Exponential } \\
\text { coefficient } \\
\text { (daytime) }\end{array}$ & $\begin{array}{l}\gamma \text { Exponential } \\
\text { coefficient } \\
\text { (nighttime) }\end{array}$ & $\begin{array}{l}\gamma_{1} \text { Canopy } \\
\text { scale }(\mathrm{m}) \\
\text { (daytime) }\end{array}$ & $\begin{array}{l}\gamma_{1} \text { Canopy } \\
\text { scale }(\mathrm{m}) \\
\text { (nighttime) }\end{array}$ & $\begin{array}{l}\gamma_{\mathrm{p}} \text { Exponential } \\
\text { coefficient PAR }\end{array}$ \\
\hline Jackpine & 0.059 & 0.070 & 0.63 & 0.76 & 8.5 & 10.2 & 0.60 \\
\hline Hyytiala & 0.071 & 0.065 & 0.75 & 0.66 & 10.4 & 9.5 & 0.67 \\
\hline Wind River & 0.015 & 0.011 & 0.31 & 0.22 & 20.8 & 14.6 & 0.54 \\
\hline Le Bray & 0.039 & 0.041 & 0.49 & 0.52 & 9.8 & 10.3 & - \\
\hline Metolius & 0.039 & 0.047 & 0.44 & 0.53 & 10.6 & 10.6 & - \\
\hline Blodgett & - & - & - & - & - & - & 0.57 \\
\hline Aspen & 0.054 & 0.055 & 0.71 & 0.72 & 15.2 & 15.5 & 0.55 \\
\hline Hesse & 0.024 & 0.018 & 0.29 & 0.21 & 4.7 & 3.4 & - \\
\hline Walker Branch & 0.020 & 0.017 & 0.24 & 0.20 & 6.3 & 5.2 & 0.43 \\
\hline Tonzi & 0.18 & 0.18 & 1.28 & 1.32 & 9.1 & 9.4 & 0.82 \\
\hline
\end{tabular}

$c_{\mathrm{d}}$, Canopy drag coefficients; $\gamma$, exponential extinction coefficient for the canopy with respect to canopy leaf area index LAI; $\gamma_{1}$, length scale for the canopy associated with $\gamma ; \gamma_{\mathrm{P}}$ is an exponential coefficient for the extinction of PAR in a canopy. 

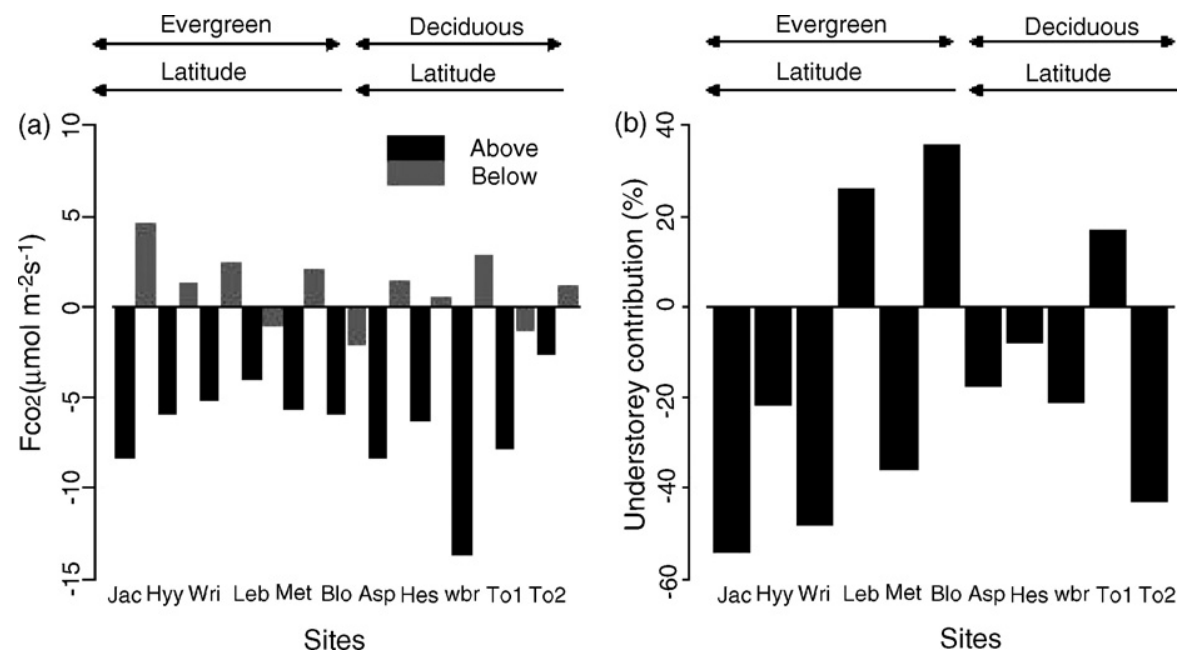

Fig. 3. (a) Mean summer daytime net $F_{\mathrm{CO}_{2}}$ fluxes above and below the main canopy and (b) mean summer daytime net $F_{\mathrm{CO}_{2}}$ understory contribution. Sites abbreviations are shown in Table 2.

temperature, high soil moisture and the presence of a very active herbaceous understory $\left(\mathrm{LAI}_{\mathrm{B}}=0.7 \mathrm{~m}^{2} \mathrm{~m}^{-2}\right)$ during early summer. The understory contribution to total canopy $\mathrm{GPP}_{\mathrm{A}}$ varied between $0 \%$ and $39 \%$, with an average of $14 \%$ across the studied sites (Fig. 4b). Variations of this contribution across sites could not be explained by $\mathrm{LAI}_{\mathrm{B}}$ or $\mathrm{PAR}_{\mathrm{B}}$ at the forest floor alone (not shown). By taking into account variations of $\mathrm{LAI}_{\mathrm{B}}$ and $\mathrm{PAR}_{\mathrm{B}}$ in the understory together, a significant relationship was found with variations of photosynthetic uptake, both in absolute values and in relative contribution (Fig. 5a and b). Scatter around this relationship indicates that other factors played a role. In particular, the Aspen site (Asp) showed a significant deviation from the main relationship found for the other sites: $\mathrm{GPP}_{\mathrm{B}}$ of the understory remained low despite relatively high penetration of radiation to the understory $\left(\sim 140 \mu \mathrm{mol} \mathrm{m}^{-2} \mathrm{~s}^{-1}\right)$ and dense understory vegetation (hazelnut, $\mathrm{LAI}_{\mathrm{B}}$ $3.2 \mathrm{~m}^{2} \mathrm{~m}^{-2}$ ) (Fig. 5a and b). Thus, the Aspen site indicated minimal photosynthesis by the understory for the amount of radiation and leaf area.

\subsection{Nighttime $\mathrm{CO}_{2}$ fluxes}

We calculated the probability $p$ (see Eq. (15)) for different $u^{*}$ thresholds at the top of the canopy ranging
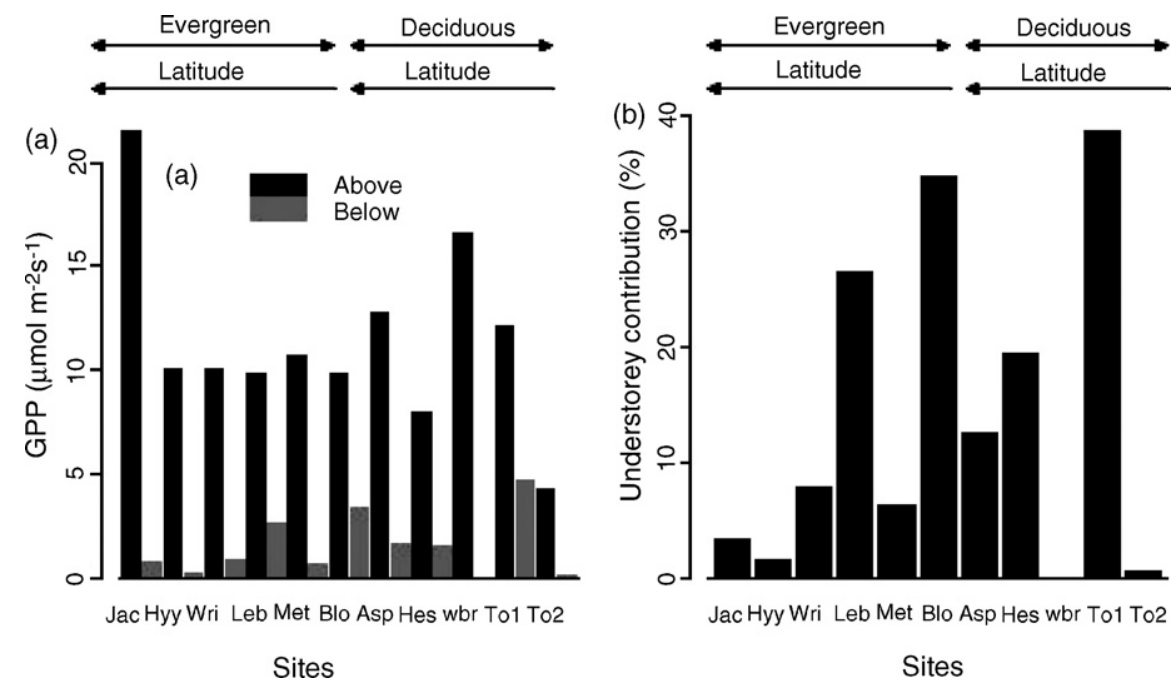

Fig. 4. (a) Mean summer daytime GPP fluxes above and below the main canopy and (b) mean summer daytime understory GPP contribution. Sites abbreviations are shown in Table 2. 

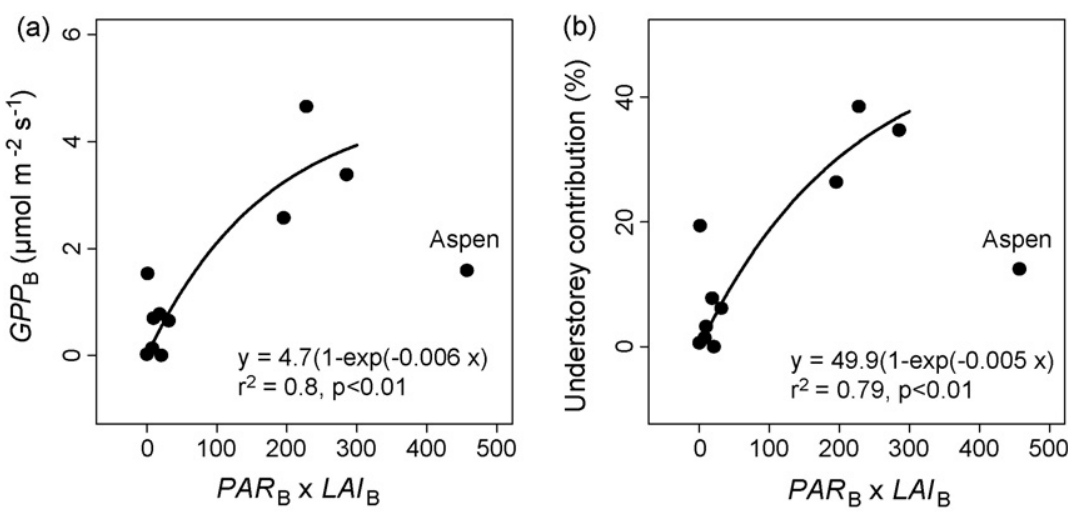

Fig. 5. (a) GPP below the main canopy (see Fig. 4a) and (b) GPP understory contribution (see Fig. 4b), as a function of $P R_{B} \times L_{B}$.

from $>0.3$ to $>0.6 \mathrm{~m} \mathrm{~s}^{-1}$. Irrespective of the $u^{*}$ threshold, the probability of gas transport out of canopy, $p$, seems to be inversely related with the leaf area index of the main canopy, as shown in Fig. 6 for a $u^{*}$ of $0.4 \mathrm{~m} \mathrm{~s}^{-1}$. However, this relationship was not significant, even when discarding the outlier at Walker Branch. Discarding this outlier, $p$ varied between 1.0 and 0.8 amongst sites, with most of the sites having $p \sim 0.85$. These data suggest that at most sites, at least $15 \%$ of the $\mathrm{CO}_{2}$ produced in the understory was recycled and assimilated by leaves during the early hours of the day, without passing the level of the above canopy eddy-covariance system (Fig. 6).

Mean nighttime fluxes of $\mathrm{CO}_{2}$ above canopy varied between 2.3 and $8.4 \mu \mathrm{mol} \mathrm{m} \mathrm{s}^{-2} \mathrm{~s}^{-1}$, while fluxes beneath ranged between 0.7 and $5.4 \mu \mathrm{mol} \mathrm{m}^{-2} \mathrm{~s}^{-1}$ (Fig. 7a). The understory flux contribution to the above canopy flux varied between $32 \%$ and $79 \%$, with an average around $55 \%$ (Fig. 7b). Understory in deciduous

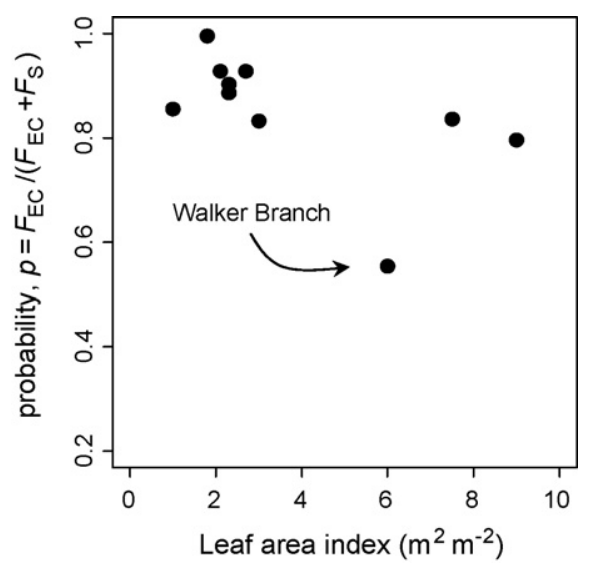

Fig. 6. Probability $p=F_{\mathrm{EC}} /\left(F_{\mathrm{EC}}+F_{\mathrm{s}}\right)$ of gas transport out of the canopy as a function of leaf area index. forests had higher contributions (62\%) than in evergreen forests (49\%) (Fig. 7b). Boreal and temperate forests had a mean contribution of $\sim 61 \%$ while arid/ semi-arid forests generally had lower values (44\%) (Fig. 7b). At the oak savanna site, where the climate was the most arid, both above and below canopy fluxes were reduced in late summer (To2) compared to early summer (To1), while the understory contribution to the above canopy fluxes decreased from $48 \%$ to $32 \%$ (Fig. 7b). At the Metolius ponderosa pine site, the understory flux contribution of $62 \%$ was higher than expected considering the location in a semi-arid climate with a very dry summer (Irvine et al., 2004).

In an attempt to explain variation in understory $\mathrm{CO}_{2}$ efflux during night between the sites, we plotted mean summer below canopy fluxes as a function of mean soil temperature (Fig. 8a). A negative relationship was found, but it was not statistically significant. Effluxes were normalized for short-term soil temperature changes and soil moisture variations at each site. For soil temperature, we used a $Q_{10}$ relationship established at each site during well ventilated summer nights (see Appendices $\mathrm{C}$ and D) to calculate $\mathrm{F}_{\mathrm{CO}_{2}}$ at $20{ }^{\circ} \mathrm{C}$ $\left(F_{\mathrm{CO}_{2}, \mathrm{~B}\left(20^{\circ} \mathrm{C}\right)}\right)$. For soil water, we divided $F_{\mathrm{CO}_{2}, \mathrm{~B}\left(20^{\circ} \mathrm{C}\right)}$ by relative soil moisture (RSM) during summer, which is the average soil moisture at $10 \mathrm{~cm}$ measured at each site divided by the soil moisture at maximum field capacity (Howard and Howard, 1993; Rovira, 1953). The normalized efflux for soil temperature and soil moisture was negatively and significantly correlated with soil temperature, suggesting a temperature acclimation of soil respiration, with higher normalized respiration at lower temperature $\left(r^{2}=0.64, p<0.01\right.$; Fig. 8 b). However, soil carbon content was probably a confounding factor: we effectively found a positive relationship between carbon content of the first $10 \mathrm{~cm}$ 


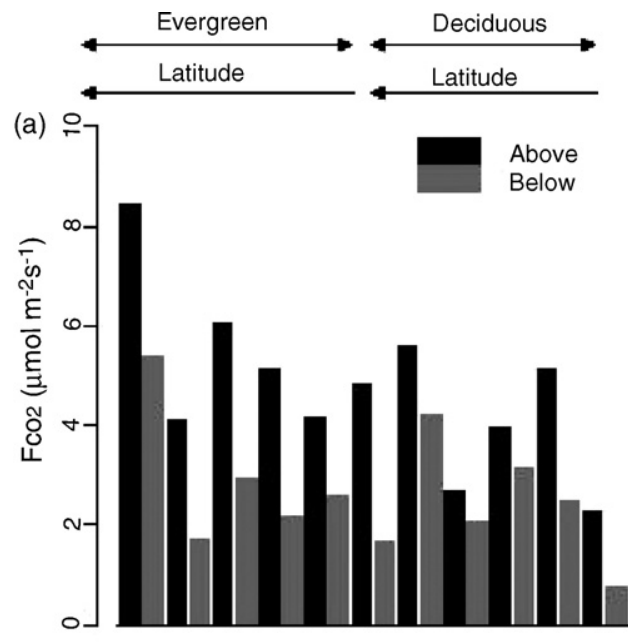

Jac HyyWri Leb Met Blo Asp Hes Wbr To1 To2

Sites

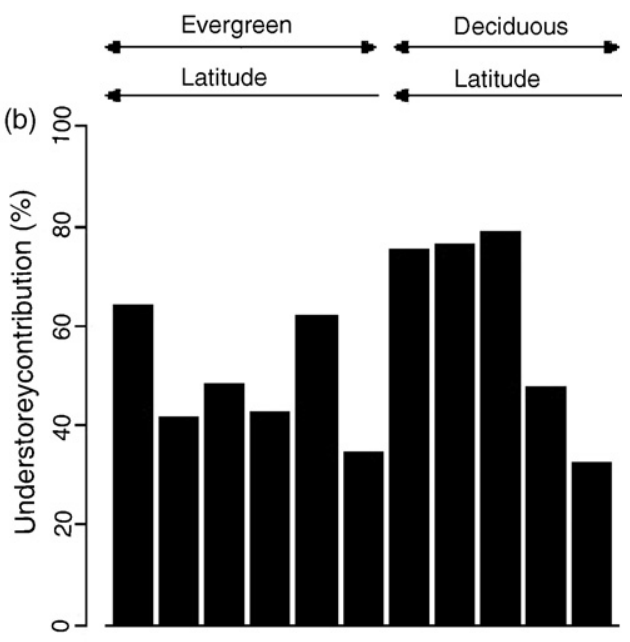

Jac HyyWri Leb Met Blo Asp Hes Wbr To1 To2

Sites

Fig. 7. (a) Mean summer nighttime $F_{\mathrm{CO}_{2}}$ fluxes above and below the main canopy and (b) mean summer nighttime $F_{\mathrm{CO}_{2}}$ understory contribution. Sites abbreviations are shown in Table 2.
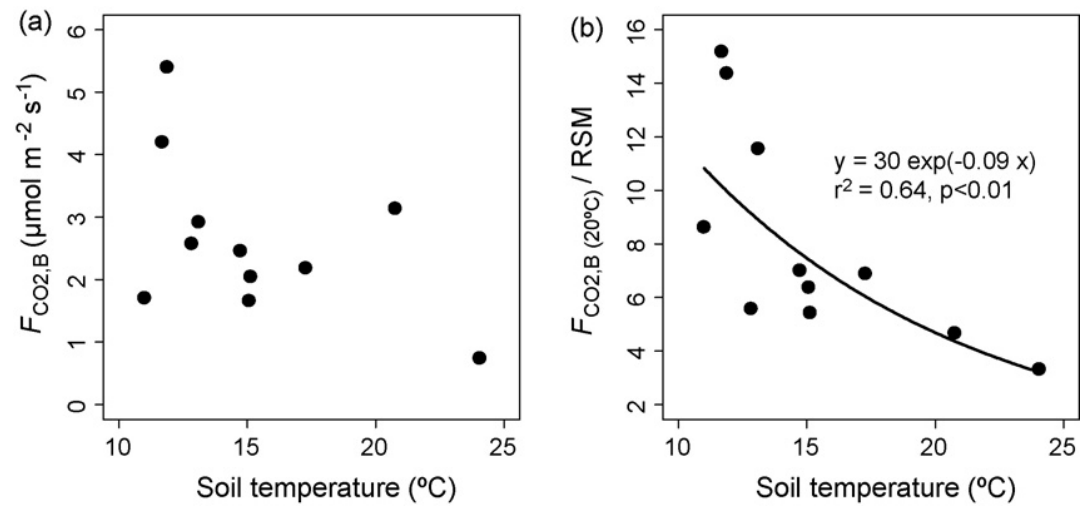

Fig. 8. (a) Nighttime understory $\mathrm{CO}_{2}$ efflux and (b) normalized efflux for soil temperature and moisture, as a function of soil temperature.
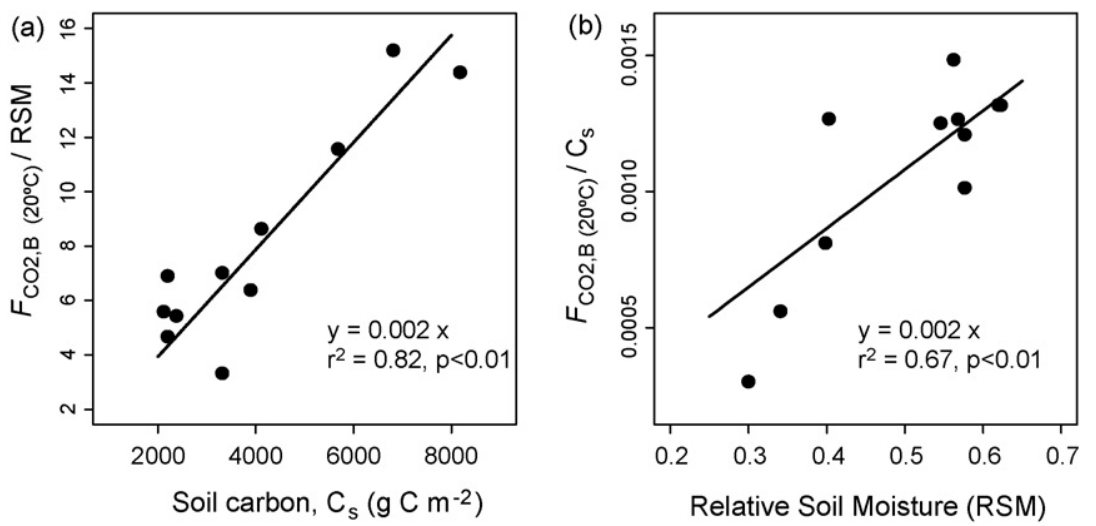

Fig. 9. (a) Normalized efflux for soil temperature and moisture, as a function of soil carbon and (b) normalized efflux for soil temperature and soil carbon, as a function of soil moisture. 


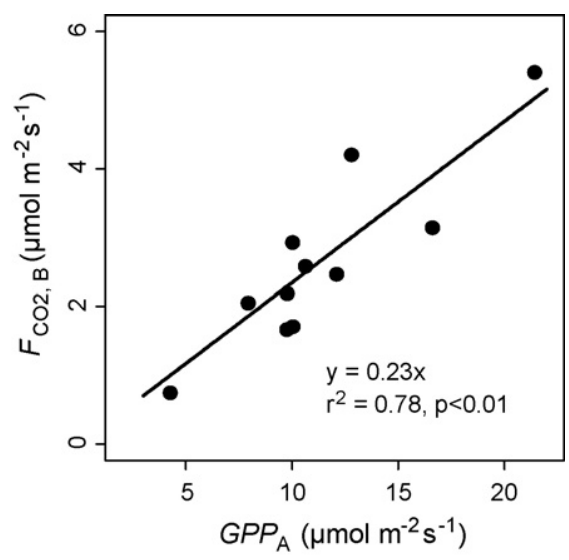

Fig. 10. Nighttime understory $\mathrm{CO}_{2}$ flux below the main canopy as a function of whole canopy GPP.

of the soil $\left(\mathrm{g} \mathrm{C} \mathrm{m}^{-2}\right)$ and the normalized understory efflux for soil temperature and soil moisture $F_{\mathrm{CO}_{2}, \mathrm{~B}\left(20^{\circ} \mathrm{C}\right)} / \mathrm{RSM}\left(r^{2}=0.82, p<0.01\right.$; Fig. 9a). This indicates that soil respiration at constant temperature and soil moisture was higher where there was more substrate. While it is clear that, in general, boreal forests have both the lowest soil temperature and the highest soil carbon content, the relationships in Figs. 8b and 9a were partially independent because soil carbon content and soil temperature were not significantly correlated in our dataset $\left(r^{2}=0.26, p=0.11\right.$, not shown). Some sites such as Metolius, had low soil carbon content and lower than average soil temperature, while other sites such as Tonzi, had high soil carbon content and a higher than average temperature. Differences between sites in longterm climate (e.g. annual precipitation), soil type, ecosystem management and disturbance history may explain these variations. However, the size of the database and the lack of standardized data for some of these factors preclude further analyses for the moment.

Another way to investigate these relationships is to look at the reciprocal of the relationship found in Fig. 9a, which shows the variation of the normalized efflux for temperature and soil carbon, as a function of relative soil moisture (Fig. 9b). The $y$-axis represents the understory flux per gram of carbon in the soil, at constant temperature of $20^{\circ} \mathrm{C}$ : it gives an idea of the microbial metabolic activity, showing a decrease in efficiency when soil moisture decreases $\left(r^{2}=0.67\right.$, $p<0.01$; Fig. 9b). Finally, we found a significant positive relationship between whole canopy photosynthesis and understory efflux across sites. Thus, ecosystems that assimilated more carbon had higher respiration fluxes in the understory, with a ratio of 0.23 between both fluxes $\left(r^{2}=0.78, p<0.01\right.$; Fig. 10).

\section{Discussion}

Directional wind shear in the planetary boundary layer and in plant canopies is a result of the balance between Coriolis effects and the pressure gradient, far above the canopy with approximately geostrophic flow in the free atmosphere, and frictional drag forces which dominate near the surface resulting in near anti-triptic winds (Kondo and Akashi, 1976; Lee et al., 1994; Pinker and Holland, 1988; Pyles et al., 2004; Shinn, 1971; Smith et al., 1972; Staebler and Fitzjarrald, 2005). Deflection in the wind vector is thus expected to vary for different amounts of drag force (friction), consistent with the difference in wind direction observed between the top of the canopy $\left(W_{\mathrm{D}, \mathrm{A}}\right)$ and the forest floor $\left(W_{\mathrm{D}, \mathrm{B}}\right)$ increasing with leaf area index (Fig. 1b). This effect is of different magnitude between day and night, because of the diurnal changes of the pressure gradient force, stability-associated turbulence levels affecting momentum coupling and wind speed. However, wind deflection in the canopy presented in Fig. 1b are very high and not always to the left as they should be in the Northern hemisphere. Thus, advective flow induced by topography or spatial variation in understory vegetation may be important, influencing a preferred direction to the flow in the stable layer near the forest floor (Lee, 2000; Mahrt et al., 2000; Pyles et al., 2004; Staebler and Fitzjarrald, 2005). These effects, associated with local, regional pressure gradients differences compared to synoptic scale gradients, are usually more important at night than during the day when turbulence mixing and therefore linkage to synoptic forcing is stronger. Thus, how much $W_{\mathrm{D}, \mathrm{A}}-W_{\mathrm{D}, \mathrm{B}}$ varies between day and night partly reflects the magnitude of topographical effects at a given site. This difference varies between $3^{\circ}$ and $34^{\circ}$ amongst the investigated sites, with an average of $12^{\circ}$.

We found that daytime air temperature is generally higher above the understory than at the top of the canopy for open canopies (Fig. 1c). Open canopies receive more solar energy at the soil surface, so the soil temperature is much greater and amplifies this difference (Campbell, 1977). Closed canopies have shaded soil, so the air temperature in the understory is lower. On the other hand, the nocturnal temperature inversion is stronger for open canopies because radiative cooling of the understory is more important when not obstructed by the main canopy above (Granberg et al., 1993; Lee and Mahrt, 2005; Mahrt et al., 2000; Nunez and Bowman, 1986; Oliver et al., 1987) (Fig. 1d). As a consequence of the development of strong nighttime stable stratification for forests with low LAI, we found that attenuation of $u^{*}$ in the canopy 
is higher at night than during the day (Fig. 2a). In contrast, radiative cooling at the canopy top and sensible heat flux from the soil destabilize the air at the forest floor under high LAI (Jacobs et al., 1994; Kruijt et al., 2000; Shuttleworth et al., 1984). In these high LAI forests, stratification may become neutral or even unstable at night below the canopy and influences the development of relatively strong and independent turbulence regimes understory (Amiro, 1990; Falk et al., 2005; Jacobs et al., 1994; Lee and Mahrt, 2005; Mahrt et al., 2000; Shuttleworth et al., 1984). Consequently, attenuation of $u^{*}$ in the canopy is lower at night than during the day for forests with high LAI (Fig. 2a). Differences in topography between sites might explain part of the scatter found in the relationships presented in Fig. 2a.

We showed that the coupling between $u^{*}$ above and below the main canopy is: (1) inversely related to LAI, (2) higher during the day than at night and (3) lower at night for closed canopies (Fig. 2b). Most of the turbulent fluxes in plant canopies are transported by relatively short-duration periodic sweeps and ejections (Baldocchi and Meyers, 1988; Gao et al., 1989; Lee and Black, 1993). During daytime neutral or unstable conditions, a certain level of coupling exists between turbulence above and below the canopy (Fig. 2b), even if coherent downward sweeps do not always penetrate into the lower part of the canopy, especially for tall forests and high LAI (Kruijt et al., 2000). During the night, this coupling decreases because coherent events do not penetrate through the understory inversion layer (Kruijt et al., 2000; Mahrt et al., 2000) (Fig. 2b). We showed that at night in closed canopies, the inversion is less strong than in more open canopies (Fig. 1d). However, the coupling decreases more in closed than in open canopies because there is a more independent turbulence regime at the forest floor, as explained above (Amiro, 1990; Jacobs et al., 1994; Kruijt et al., 2000; Lee and Mahrt, 2005; Mahrt et al., 2000; Shuttleworth et al., 1984). So during nighttime, turbulence is suppressed in open canopies, while turbulence is independent from above canopy conditions in close canopies, so in both cases turbulence above and below the main canopy is decoupled.

In contrast to the coupling coefficient analysis, the traditional micrometeorological canopy parameters for $u^{*}$ do not show a clear diurnal pattern (Table 3). The canopy and drag coefficients vary by up to $25 \%$ between night and day, but whereas some increase between night and day, others decrease, and some are almost constant, depending on canopy. The canopy and drag coefficients are compatible with previous literature values (Inoue,
1963; Cionco, 1965, 1972; Smith et al., 1972; Thom, 1975; Raupach and Thom, 1981; Meyers and Paw U, 1986; Raupach, 1987), but the drag coefficients are inversely proportional to the leaf area index. This may be a result of how the within-canopy length scale is defined in the analysis, which results in the drag coefficient equation showing an inverse proportionality relationship. The canopy scale ranged from 3 to $21 \mathrm{~m}$ for the tallest canopy, the Wind River site. The radiation extinction coefficients ranged from 0.43 to 0.82 , well within the range of values found in the literature (Ross, 1975).

In conclusion, we showed that eddy-covariance flux measurements understory are problematic at night in open forests because of the build up of a strong inversion layer, but are more reliable during the day. Denser forests have higher turbulence at night in the understory because the inversion is weaker. However, the flux footprint above and below canopy is probably less similar than in more open forests, because wind direction is more deflected while entering the canopy. A further paper is in preparation investigating above and below canopy flux footprints, and the influence of thermal stability.

PAR attenuation in the canopy follows an exponential relationship with LAI, similarly to a filter that reduces light according to Beer-Lambert Law (e.g. Jones, 1992; Vose et al., 1995). This relationship is nothing new scientifically, but its presentation is important to rank the attributes of the canopies under investigation. Notice that the equation presented in Fig. $1 \mathrm{~b}$ includes an intercept at 0.64 , while the original exponential equation does not (intercept $=0$ ). This difference allows us to account for variations in clumping factors and leaf angles between sites, which were not readily available. The equation presented in Fig. 1a could serve as a broader equation in modeling studies across different sites when clumping factors are not available.

Averaging periods for computing the mean daytime and nighttime fluxes reported in Figs. 3 and 4 could be viewed as arbitrary, because there are no apparent controls for time of the year. However, instead of averaging for similar time periods, we decided to average for similar phenological phases based on knowledge about development of leaf area index overand understory, and seasonal evolution of the above and below canopy fluxes. In this manner, we can compare fluxes for the same phenological phase but for widely different ecosystems (from Mediterranean to boreal), for which the period characterized by the presence of a full canopy and active $\mathrm{CO}_{2}$ sequestration occurs at different times of the year. 
We expected to see a stronger relationship between light and LAI understory because forests with low overstory LAI have higher light penetration below the canopy, which could influence positively the development of a denser vegetation understory. However, leaf area index of the understory seems to be more related to the overall productivity of the site under controls of the site water balance, because in some regions specific species are adapted to develop under very low light conditions. We showed that GPP of the understory can reach $39 \%$ of the total canopy GPP, with an average of $14 \%$ across the studied sites (Fig. 4b). Other studies showed that understory vegetation may represent a considerable fraction of the overall leaf area index and therefore contributes significantly to the net gas exchange of a forest stand (e.g. Wedler et al. (1996), $20 \%$ of NPP; Moren and Lindroth (2000), $700 \mathrm{~g} \mathrm{C} \mathrm{m}^{-2}$; Subke and Tenhunen (2004), 3-12\% of GPP). Our study showed that both understory LAI and light penetration through the canopy as a function of overstory LAI are important for forest floor GPP, and that both factors are not necessarily correlated. However, the relationships shown in Fig. 5a and $\mathrm{b}$ have significant scatter indicating that additional factors are likely to be important. Analyzing and modeling GPP of understory may require accounting for sunflecks and the partitioning of total radiation into its diffuse and direct components (Koizumi and Oshima, 1993; Kolari et al., 2006; Pfitsch and Pearcy, 1989). In addition, variation in photosynthetic capacity of the understory is probably an essential factor to consider for understory GPP (Misson et al., 2006b). Baldocchi and Wilson (2001) showed that for a given radiation, GPP varies with both the LAI and the photosynthetic capacity of the canopy, especially for sparse and less productive canopies such as understories. A low photosynthetic capacity of the understory vegetation in the boreal Aspen site might explain why understory GPP is low besides having high LAI and adequate radiation (Blanken and Black, 2004). Middleton et al. (1997) showed that photosynthetic capacity of aspen is often double (or more) that of hazelnut in several BOREAS sites. However, our $13 \%$ summertime understory GPP contribution for this site might be low considering that Black et al. (1996) found a $32 \%$ contribution. This discrepancy might be partly due to different turbulence mixing thresholds used. However, it was necessary for this paper to keep a consistent methodology across the investigated sites.

We found that understory respiration contributed an average of $55 \%$ to ecosystem respiration, with a range of $32-79 \%$ (Fig. 7b). Most of the understory fluxes probably originate from soil respiration, with a minor contribution from aboveground parts of understory vegetation, except when this vegetation is very dense, for example, at the Aspen (75\%) and Wind River (48\%) sites. These contributions are in the range of reported soil respiration contributions to total ecosystem respiration, but generally in the lower fraction of values reported (Davidson et al., 1998; Gaumont-Guay et al., 2006; Janssens et al., 2001b; Lavigne et al., 1997; Law et al., 1999, 2001b; Xu et al., 2001; Curiel Yuste et al., 2005). Our somewhat lower values maybe due to underestimation of the understory fluxes by the eddycovariance method at night, even under high friction velocity conditions. We found that understory in deciduous forests had higher contributions (62\%) to ecosystem respiration than in evergreen forests (49\%). Nitrogen is typically a limiting factor for soil carbon decomposition in forest ecosystems. Several studies have shown that deciduous trees typically concentrate more nutrients in the leaves than evergreen species (Reich et al., 2003), which is reflected in the palatability of the substrate produced by both leaf strategies (Joffre et al., 2001). The difference in the understory contribution between evergreen and deciduous sites might thus be partially attributed to differences in the quality of the soil organic matter (Curiel Yuste et al., 2004). This is suggested by higher C:N ratios that we found for soils under evergreen species (31) than for soil under deciduous species (16).

The temperature sensitivity of decomposition of soil organic matter is of significant interest because of its importance in the global carbon cycle and the potential feedback to climate change (Davidson and Janssens, 2006). Our analyses show that normalized understory respiration fluxes at $20^{\circ} \mathrm{C}$ are negatively related to soil temperature, when differences in soil moisture across the sites are taken into account (Fig. 8b). This relationship may be explained because understory fluxes are probably dominated by soil respiration, and soil developed under cold climate contains a larger amount of labile soil organic matter than soil developed under warmer climate (Anderson, 1992; Kirschbaum, 1995; Schlesinger and Andrews, 2000) (Fig. 9a). However, thermal acclimation has been commonly observed, both for plant respiration (Atkin et al., 2005) and microbial community composition and activity (Zhang et al., 2005; Zogg et al., 1997). Thus, because the relationship in Fig. $8 \mathrm{~b}$ is partially independent of variations of soil carbon content between the sites (Fig. 9a), we also interpret this as partial evidence of an acclimation of soil respiration to soil temperature, independently of substrate availability, quality, and disturbance effects. Valentini et al. (2000) showed that 
ecosystem respiration was more related to latitude than to mean annual air temperature (see also Giardina and Ryan, 2000), and this relationship is probably driven by both the high availability of soil organic matter in a labile form in high latitude sites (Anderson, 1992; Kirschbaum, 1995; Schlesinger and Andrews, 2000), and drought limitation to soil respiration in lower latitude sites (Borken et al., 2006). The latter is clearly illustrated in Fig. 9b, showing that the efficiency of microbial metabolic activity decreases when relative soil moisture decreases. Expressing soil moisture in a relative way has been show to produce a better correlation with microbial activity than absolute values of soil moisture content (Howard and Howard, 1993; Rovira, 1953).

Understory respiration fluxes were positively correlated with gross ecosystem productivity among the investigated sites (Fig. 10), which confirms the hypothesis that difference in soil respiration among a range of forests are likely to depend more on productivity than on temperature (Janssens et al., 2001b). A control of substrate supply on soil respiration has been shown previously, both for short-term variation (Hogberg et al., 2001; Misson et al., 2006a; Tang et al., 2005) and across sites varying in productivity (Campbell et al., 2004; Janssens et al., 2001b; Reichstein et al., 2003), partly because root respiration is constrained by the allocation of photosynthates belowground. In addition, a large faction of heterotrophic respiration comes from decomposition of labile organic matter, whose availability also depends on ecosystem productivity. Plant metabolism (Hogberg et al., 2001) or the decomposition of recently produced organic material (Giardina et al., 2004; Giardina and Ryan, 2002; Trumbore, 2000) generates most of the soil respiration and soil respiration strongly reflects this plant metabolism (Bowling et al., 2002; Ekblad and Hogberg, 2001).

\section{Conclusion}

This paper presented the first analysis of understory eddy-covariance $\mathrm{CO}_{2}$ flux measurement for different forests selected across a wide range of type, structure and climate. We showed that in open forests, understory eddy-covariance flux measurements can be problematic at night due to the build up of a strong inversion layer, and in denser forests because the flux footprint above and below canopy is less similar than in open forests. We showed that the understory can contribute significantly to whole ecosystem photosynthetic sinks and respiration sources. However, variations between sites were important for both sinks and sources, and were related to difference in leaf area index, canopy composition (evergreen versus deciduous) and climate (boreal, temperate and arid/semi-arid). Understory GPP contribution ranged between $0 \%$ and $39 \%$ of total ecosystem GPP, and was related to understory LAI and light penetration. Understory respiration ranged between $32 \%$ and $79 \%$ of total ecosystem respiration, and was related to substrate availability (GPP, soil carbon) and quality (soil C:N ratio), soil temperature and soil moisture content. Taking into account these factors and how they affect the flux partitioning between overstory and understory is crucial to fully understand, quantify and predict the influence of forests on atmospheric composition and climate.

\section{Acknowledgments}

This work was made possible by grants from the Kearney Foundation of Soil Science, the University of California Agricultural Experiment Station and the Office of Science, Biological and Environmental Research Program (BER), U.S. Department of Energy, through the Western Regional Center of the National Institute for Global Environmental Change (NIGEC) under Cooperative Agreement No. DE-FCO203ER63613. This research is also a contribution to the Carboeurope, Ameriflux, Fluxnet-Canada and Fluxnet projects. Financial support does not constitute an endorsement of the views expressed in this article/report.

\section{Appendix A}

Symbols, definitions and units

\begin{tabular}{|c|c|c|}
\hline Symbols & Definitions & Units \\
\hline$b$ & $\begin{array}{l}\text { Coupling coefficient, } u_{\mathrm{B}}^{*}=a+b u_{\mathrm{A}}^{*} \\
\text { (Eq. (3)) }\end{array}$ & \\
\hline$F_{\mathrm{CO}_{2}}$ & Net $\mathrm{CO}_{2}$ flux & $\mu \mathrm{mol} \mathrm{m} \mathrm{s}^{-1}$ \\
\hline$F_{\mathrm{CO}_{2}, \mathrm{~A}}$ & Net $\mathrm{CO}_{2}$ flux above the canopy & $\mu \mathrm{mol} \mathrm{m}{ }^{-2} \mathrm{~s}^{-1}$ \\
\hline$F_{\mathrm{CO}_{2}, \mathrm{~B}}$ & Net $\mathrm{CO}_{2}$ flux below the canopy & $\mu \mathrm{mol} \mathrm{m}{ }^{-2} \mathrm{~s}^{-1}$ \\
\hline$F_{\mathrm{CO}_{2}, \mathrm{~B}\left(20^{\circ} \mathrm{C}\right)}$ & $\begin{array}{l}\text { Nighttime } \mathrm{CO}_{2} \text { flux below the canopy } \\
\text { at } 20 \mathrm{C} \text { soil temperature }\end{array}$ & $\mu \mathrm{mol} \mathrm{m}{ }^{-2} \mathrm{~s}^{-1}$ \\
\hline$F_{\mathrm{EC}, \mathrm{A}}$ & Eddy-covariance flux above the canopy & $\mu \mathrm{mol} \mathrm{m}{ }^{-2} \mathrm{~s}^{-1}$ \\
\hline$F_{\mathrm{s}}$ & Storage flux & $\mu \mathrm{mol} \mathrm{m}{ }^{-2} \mathrm{~s}^{-1}$ \\
\hline GPP & Gross primary productivity & $\mu \mathrm{mol} \mathrm{m}{ }^{-2} \mathrm{~s}^{-1}$ \\
\hline $\mathrm{GPP}_{\mathrm{A}}$ & $\begin{array}{l}\text { Gross primary productivity above } \\
\text { the canopy }\end{array}$ & $\mu \mathrm{mol} \mathrm{m}^{-2} \mathrm{~s}^{-1}$ \\
\hline $\mathrm{GPP}_{\mathrm{B}}$ & $\begin{array}{l}\text { Gross primary productivity below } \\
\text { the canopy }\end{array}$ & $\mu \mathrm{mol} \mathrm{m}^{-2} \mathrm{~s}^{-1}$ \\
\hline$K$ & Extinction coefficient & \\
\hline LAI & Leaf area index & $\mathrm{m}^{2} \mathrm{~m}^{-2}$ \\
\hline $\mathrm{LAI}_{\mathrm{A}}$ & Leaf area index of the overstory & $\mathrm{m}^{2} \mathrm{~m}^{-2}$ \\
\hline $\mathrm{LAI}_{\mathrm{B}}$ & Leaf area index of the understory & $\mathrm{m}^{2} \mathrm{~m}^{-2}$ \\
\hline$p$ & $\begin{array}{l}\text { Probably of gas transport out of } \\
\text { canopy (Eq. (10)) }\end{array}$ & Fraction \\
\hline
\end{tabular}


Appendix A (Continued)

\begin{tabular}{lll}
\hline Symbols & Definitions & Units \\
\hline PAR & Photosynthetically active radiation & $\mu \mathrm{mol} \mathrm{m}^{-2} \mathrm{~s}^{-1}$ \\
PAR $_{\mathrm{A}}$ & PAR above the canopy & $\mu \mathrm{mol} \mathrm{m}^{-2} \mathrm{~s}^{-1}$ \\
PAR $_{\mathrm{B}}$ & PAR below the canopy & $\mu \mathrm{mol} \mathrm{m}^{-2} \mathrm{~s}^{-1}$ \\
$R_{\mathrm{A}}$ & Respiration above the canopy & $\mu \mathrm{mol} \mathrm{m}^{-2} \mathrm{~s}^{-1}$ \\
$R_{\mathrm{B}}$ & Respiration below the canopy & $\mu \mathrm{mol} \mathrm{m}^{-2} \mathrm{~s}^{-1}$ \\
$\mathrm{RSM}$ & Relative soil moisture & Fraction \\
$T_{\mathrm{A}}$ & Air temperature above the canopy & ${ }^{\circ} \mathrm{C}$ \\
$T_{\mathrm{B}}$ & Air temperature below the canopy & ${ }^{\circ} \mathrm{C}$ \\
$T_{\mathrm{S}}$ & Soil temperature at $10 \mathrm{~cm}$ & ${ }^{\circ} \mathrm{C}$ \\
$u^{*}$ & Friction velocity & $\mathrm{m} \mathrm{s}^{-1}$ \\
$u_{\mathrm{A}}^{*}$ & Friction velocity above the canopy & $\mathrm{m} \mathrm{s}^{-1}$ \\
$u_{\mathrm{B}}^{*}$ & Friction velocity below the canopy & $\mathrm{m} \mathrm{s}^{-1}$ \\
$W_{\mathrm{D}, \mathrm{A}}$ & Wind direction above the canopy & ${ }^{\circ}$ \\
$W_{\mathrm{D}, \mathrm{A}}$ & Wind direction below the canopy & ${ }^{\circ}$ \\
\hline
\end{tabular}

\section{Appendix B}

Summer period and year of available data for the investigated sites

\begin{tabular}{lll}
\hline Site & Summer & Year \\
\hline Jackpine & >Day 142 and < day 260 & 1994 \\
Hyytiala & >Day 110 and < day 245 & 2004 \\
Wind River & >Day 110 and < day 250 & 1999 \\
Le Bray & >Day 120 and < day 240 & 2002 \\
Metolius & >Day 124 and < day 261 & 2004 \\
Blodgett & >Day 130 and < day 250 & 2003 \\
Aspen & >Day 160 and < day 240 & 1994 \\
Hesse & >Day 182 and < day 260 & 2004 \\
Walker Branch & $>$ Day 130 and < day 250 & 1999 \\
Tonzi, To1 & $>$ Day 90 and < day 150 & 2003 \\
Tonzi, To2 & $>$ Day 150 and < day 250 & 2003 \\
\hline
\end{tabular}

\section{Appendix C}

$u^{*}$ threshold and temperature exponential relationship for nighttime $\mathrm{CO}_{2}$ flux below the canopy

\begin{tabular}{llllll}
\hline Site & $u^{*}$ threshold $\left(\mathrm{m} \mathrm{s}^{-1}\right)$ & $a^{\mathrm{a}}$ & $b^{\mathrm{a}}$ & $Q_{10}{ }^{\mathrm{b}}$ & $n^{\mathrm{c}}$ \\
\hline Jackpine & 0.022 & 1.71 & 0.07 & 2.00 & 281 \\
Hyytiala & 0.040 & 0.29 & 0.14 & 4.02 & 184 \\
Wind River & 0.033 & 0.97 & 0.08 & 2.15 & 332 \\
Le Bray & 0.057 & 0.18 & 0.12 & 3.48 & 315 \\
Metolius & 0.097 & 1.42 & 0.03 & 1.39 & 263 \\
Blodgett & 0.091 & 0.18 & 0.10 & 2.71 & 179 \\
Aspen & 0.032 & 0.57 & 0.12 & 3.48 & 283 \\
Hesse & 0.028 & 0.56 & 0.08 & 2.25 & 853 \\
Walker Branch & 0.033 & 0.25 & 0.11 & 3.03 & 303 \\
Tonzi, To1 & 0.028 & 0.41 & 0.12 & 3.28 & 375 \\
Tonzi, To2 & 0.028 & 4.13 & -0.06 & 0.54 & 925
\end{tabular}

\footnotetext{
${ }^{\mathrm{a}} F_{\mathrm{CO}_{2}, \mathrm{~B}}=a \times \exp \left(b \times T_{\mathrm{s}}\right)$, where $T_{\mathrm{s}}$ is soil temperature.

${ }^{\text {b }} Q_{10}=\exp (10 \times b)$.

${ }^{c}$ Number of data points.
}

\section{Appendix D}

$u^{*}$ threshold and temperature exponential relationship for nighttime $\mathrm{CO}_{2}$ flux above the canopy

\begin{tabular}{|c|c|c|c|c|c|}
\hline Site & $u^{*}$ threshold $\left(\mathrm{m} \mathrm{s}^{-1}\right)$ & $a^{\mathrm{a}}$ & $b^{\mathrm{a}}$ & $Q_{10}{ }^{\mathrm{b}}$ & $n^{\mathrm{c}}$ \\
\hline Jackpine & 0.26 & 2.17 & 0.11 & 2.99 & 140 \\
\hline Hyytiala & 0.47 & 0.85 & 0.14 & 4.15 & 214 \\
\hline Wind River & 0.24 & 1.17 & 0.09 & 2.49 & 174 \\
\hline Le Bray & 0.34 & 1.46 & 0.08 & 2.26 & 342 \\
\hline Metolius & 0.24 & 2.71 & 0.03 & 1.39 & 968 \\
\hline Blodgett & 0.20 & 0.66 & 0.09 & 2.47 & 333 \\
\hline Aspen & 0.18 & 1.97 & 0.06 & 1.87 & 379 \\
\hline Hesse & 0.17 & 0.45 & 0.08 & 2.28 & 670 \\
\hline Walker Branch & 0.25 & 0.82 & 0.06 & 1.85 & 352 \\
\hline Tonzi, To1 & 0.13 & 1.17 & 0.08 & 2.12 & 908 \\
\hline Tonzi, To2 & 0.18 & 3.61 & -0.03 & 0.75 & 392 \\
\hline
\end{tabular}

\section{Appendix E}

$u^{*}$ thresholds for calculation of the mean fluxes in Fig. 7

\begin{tabular}{lll}
\hline Site & $\begin{array}{l}u^{*} \text { threshold above } \\
\left(\mathrm{m} \mathrm{s}^{-1}\right)\end{array}$ & $\begin{array}{l}u^{*} \text { threshold below } \\
\left(\mathrm{m} \mathrm{s}^{-1}\right)\end{array}$ \\
\hline Jackpine & 0.10 & 0.060 \\
Hyytiala & 0.20 & 0.000 \\
Wind River & 0.30 & 0.000 \\
Le Bray & 0.20 & 0.068 \\
Metolius & 0.20 & 0.076 \\
Blodgett & 0.25 & 0.162 \\
Aspen & 0.20 & 0.070 \\
Hesse & 0.40 & 0.032 \\
Walker Branch & 0.30 & 0.039 \\
Tonzi, To1 & 0.20 & 0.039 \\
Tonzi, To2 & 0.30 & 0.060 \\
\hline
\end{tabular}

\section{References}

Amiro, B.D., 1990. Comparison of turbulence statistics within 3 boreal forest canopies. Boundary Layer Meteorol. 51 (1-2), 99-121.

Anderson, J.M., 1992. Responses of soils to climate-change. Adv. Ecol. Res. 22, 163-210.

Atkin, O.K., Bruhn, D., Hurry, V.M., Tjoelker, M.G., 2005. The hot and the cold: unravelling the variable response of plant respiration to temperature. Funct. Plant Biol. 32 (2), 87-105.

Aubinet, M., et al., 2000. Estimates of the annual net carbon and water exchange of forests: the EUROFLUX methodology. Advances in Ecological Research, vol. 30, pp. 113-175.

Baldocchi, D., et al., 2001. FLUXNET: a new tool to study the temporal and spatial variability of ecosystem-scale carbon diox- 
ide, water vapor, and energy flux densities. Bull. Am. Meteorol. Soc. 82 (11), 2415-2434.

Baldocchi, D.D., 2003. Assessing the eddy-covariance technique for evaluating carbon dioxide exchange rates of ecosystems: past, present and future. Global Change Biol. 9 (4), 479-492.

Baldocchi, D.D., Law, B.E., Anthoni, P.M., 2000. On measuring and modeling energy fluxes above the floor of a homogeneous and heterogeneous conifer forest. Agric. Forest Meteorol. 102 (2-3), 187-206.

Baldocchi, D.D., Meyers, T.P., 1988. Turbulence structure in a deciduous forest. Boundary Layer Meteorol. 43 (4), 345-364.

Baldocchi, D.D., Meyers, T.P., 1991. Trace gas-exchange above the floor of a deciduous forest .1. Evaporation and $\mathrm{CO}_{2}$ efflux. J. Geophys. Res. Atmos. 96 (D4), 7271-7285.

Baldocchi, D.D., Verma, S.B., Matt, D.R., Anderson, D.E., 1986. Eddy-correlation measurements of carbon-dioxide efflux from the floor of a deciduous forest. J. Appl. Ecol. 23 (3), 967-975.

Baldocchi, D.D., Vogel, C.A., 1996. Energy and $\mathrm{CO}_{2}$ flux densities above and below a temperate broad-leaved forest and a boreal pine forest. Tree Physiol. 16 (1-2), 5-16.

Baldocchi, D.D., Vogel, C.A., Hall, B., 1997a. Seasonal variation of carbon dioxide exchange rates above and below a boreal jack pine forest. Agric. Forest Meteorol. 83 (1-2), 147-170.

Baldocchi, D.D., Vogel, C.A., Hall, B., 1997b. Seasonal variation of energy and water vapor exchange rates above and below a boreal jack pine forest canopy. J. Geophys. Res. Atmos. 102 (D24), 28939-28951.

Baldocchi, D.D., Wilson, K.B., 2001. Modeling $\mathrm{CO}_{2}$ and water vapor exchange of a temperate broadleaved forest across hourly to decadal time scales. Ecol. Model. 142 (1-2), 155-184.

Baldocchi, D.D., Xu, L.K., Kiang, N., 2004. How plant functionaltype, weather, seasonal drought, and soil physical properties alter water and energy fluxes of an oak-grass savanna and an annual grassland. Agric. Forest Meteorol. 123 (1-2), 13-39.

Black, T.A., et al., 1996. Annual cycles of water vapour and carbon dioxide fluxes in and above a boreal Aspen forest. Global Change Biol. 2 (3), 219-229.

Blanken, P.D., Black, T.A., 2004. The canopy conductance of a boreal Aspen forest, Prince Albert National Park, Canada. Hydrol. Process. 18 (9), 1561-1578.

Blanken, P.D., et al., 1998. Turbulent flux measurements above and below the overstory of a boreal Aspen forest. Boundary Layer Meteorol. 89 (1), 109-140.

Blanken, P.D., et al., 1997. Energy balance and canopy conductance of a boreal Aspen forest: partitioning overstory and understory components. J. Geophys. Res. Atmos. 102 (D24), 2891528927.

Borken, W., Savage, K., Davidson, E.A., Trumbore, S.E., 2006. Effects of experimental drought on soil respiration and radiocarbon efflux from a temperate forest soil. Global Change Biol. 12 (2), 177-193.

Bowling, D.R., McDowell, N.G., Bond, B.J., Law, B.E., Ehleringer, J.R., 2002. C-13 content of ecosystem respiration is linked to precipitation and vapor pressure deficit. Oecologia 131 (1), 113124.

Campbell, G., 1977. An Introduction to Environmental Biophysics. Springer-Verlag, New York.

Campbell, J.L., Sun, O.J., Law, B.E., 2004. Supply-side controls on soil respiration among Oregon forests. Global Change Biol. 10 (11), 1857-1869.

Cionco, R.M., 1965. A mathematical model for air flow in a vegetative canopy. J. Appl. Meteorol. 4, 517-522.
Cionco, R.M., 1972. A wind-profile index for canopy flow. Boundary Layer Meteorol. 3, 255-263.

Constantin, J., Grelle, A., Ibrom, A., Morgenstern, K., 1999. Flux partitioning between understory and overstory in a boreal spruce/ pine forest determined by the eddy-covariance method. Agric. Forest Meteorol. 98-9, 629-643.

Curiel Yuste, J., Janssens, I.A., Carrara, A., Ceulemans, R., 2004. Annual $\mathrm{Q}(10)$ of soil respiration reflects plant phenological patterns as well as temperature sensitivity. Global Change Biol. 10 (2), 161-169.

Curiel Yuste, C., Nagy, M., Janssens, I.A., Carrara, A., Ceulemans, R., 2005. Soil respiration in a mixed temperate forest and its contribution to total ecosystem respiration. Tree Physiol. 25 (5), 609619.

Davidson, E.A., Belk, E., Boone, R.D., 1998. Soil water content and temperature as independent or confounded factors controlling soil respiration in a temperate mixed hardwood forest. Global Change Biol. 4 (2), 217-227.

Davidson, E.A., Janssens, I.A., 2006. Temperature sensitivity of soil carbon decomposition and feedbacks to climate change. Nature 440 (7081), 165-173.

Denmead, O.T., Bradley, E.F., 1985. Flux gradient relationship in a forest canopy. In: Hutchinson, B.A., Hicks, B.B. (Eds.), The Forest Atmosphere Interaction, pp. 421-442.

Ekblad, A., Hogberg, P., 2001. Natural abundance of C-13 in $\mathrm{CO}_{2}$ respired from forest soils reveals speed of link between tree photosynthesis and root respiration. Oecologia 127 (3), 305-308.

Falk, M.U.K.T.P., Wharton, S., Schroeder, M., 2005. Is soil respiration a major contributor to the carbon budget within a Pacific Northwest old-growth forest? Agric. Forest Meteorol. 135 (1-4), 269283.

Fung, I.Y., Doney, S.C., Lindsay, K., John, J., 2005. Evolution of carbon sinks in a changing climate. Proc. Natl. Acad. Sci. U.S.A. 102 (32), 11201-11206.

Gao, W., Shaw, R., Paw U, K.T., 1989. Observation of organized structure in turbulent flow within and above a forest canopy. Boundary Layer Meteorol. 47, 349-377.

Gaumont-Guay, D., et al., 2006. Influence of temperature and drought on seasonal and interannual variations of soil, bole and ecosystem respiration in a boreal Aspen stand. Agric. Forest Meteorol. 140, 203-219.

Giardina, C.P., Binkley, D., Ryan, M.G., Fownes, J.H., Senock, R.S., 2004. Belowground carbon cycling in a humid tropical forest decreases with fertilization. Oecologia 139 (4), 545-550.

Giardina, C.P., Ryan, M.G., 2000. Evidence that decomposition rates of organic carbon in mineral soil do not vary with temperature. Nature 404 (6780), 858-861.

Giardina, C.P., Ryan, M.G., 2002. Total belowground carbon allocation in a fast-growing Eucalyptus plantation estimated using a carbon balance approach. Ecosystems 5 (5), 487-499.

Granberg, H.B., Ottossonlofvenius, M., Odin, H., 1993. Radiative and aerodynamic effects of an open pine Shelterwood on Calm, Clear Nights. Agric. Forest Meteorol. 63 (3-4), 171-188.

Granier, A., et al., 2000. The carbon balance of a young Beech forest. Funct. Ecol. 14 (3), 312-325.

Hogberg, P., et al., 2001. Large-scale forest girdling shows that current photosynthesis drives soil respiration. Nature 411 (6839), 789-792.

Howard, D.M., Howard, P.J.A., 1993. Relationships between $\mathrm{CO}_{2}$ evolution, moisture-content and temperature for a range of soil types. Soil Biol. Biochem. 25 (11), 1537-1546. 
Inoue, E., 1963. On the turbulent structure of airflow within crop canopies. J. Agric. Meteorol. (Jpn.) 41, 317-326.

Irvine, J., et al., 2004. Age-related changes in ecosystem structure and function and effects on water and carbon exchange in ponderosa pine. Tree Physiol. 24 (7), 753-763.

Jacobs, A.F.G., Vanboxel, J.H., Elkilani, R.M.M., 1994. Nighttime free-convection characteristics within a plant canopy. Boundary Layer Meteorol. 71 (4), 375-391.

Janssens, I.A., Kowalski, A.S., Ceulemans, R., 2001a. Forest floor $\mathrm{CO}_{2}$ fluxes estimated by eddy-covariance and chamber-based model. Agric. Forest Meteorol. 106 (1), 61-69.

Janssens, I.A., et al., 2001b. Productivity overshadows temperature in determining soil and ecosystem respiration across European forests. Global Change Biol. 7 (3), 269-278.

Janssens, I.A., Kowalski, A.S., Longdoz, B., Ceulemans, R., 2000. Assessing forest soil $\mathrm{CO}_{2}$ efflux: an in situ comparison of four techniques. Tree Physiol. 20 (1), 23-32.

Joffre, R., Agren, G.I., Gillon, D., Bosatta, E., 2001. Organic matter quality in ecological studies: theory meets experiment. Oikos 93 (3), 451-458.

Jones, H., 1992. Plants and microclimate-a quantitative approach to environmental plant physiology, second ed.

Kelliher, F.M., et al., 1999. Carbon dioxide efflux density from the floor of a central Siberian pine forest. Agric. Forest Meteorol. 94 (3-4), 217-232.

Kirschbaum, M.U.F., 1995. The temperature-dependence of soil organic-matter decomposition, and the effect of global warming on soil organic-C storage. Soil Biol. Biochem. 27 (6), $753-$ 760.

Koizumi, H., Oshima, Y., 1993. Light environment and carbon gain of understory herbs associated with Sunflecks in a warm temperature deciduous forest in Japan. Ecol. Res. 8 (2), 135-142.

Kolari, P., et al., 2006. Forest floor vegetation plays an important role in photosynthetic production of boreal forests. Forest Ecol. Manage. 221 (1-3), 241-248.

Kondo, J., Akashi, S., 1976. Numerical studie on the two dimensional flow in horizontally homogeneous forest canopy layer. Boundary Layer Meteorol. 10, 255-272.

Kruijt, B., et al., 2000. Turbulence statistics above and within two Amazon rain forest canopies. Boundary Layer Meteorol. 94 (2), 297-331.

Lamaud, E., Ogee, J., Brunet, Y., Berbigier, P., 2001. Validation of eddy flux measurements above the understory of a pine forest. Agric. Forest Meteorol. 106 (3), 187-203.

Launiainen, S., et al., 2005. Eddy-covariance measurements of $\mathrm{CO}_{2}$ and sensible and latent heat fluxes during a full year in a boreal pine forest trunk-space. Boreal Environ. Res. 10 (6), $569-588$

Lavigne, M.B., et al., 1997. Comparing nocturnal eddy-covariance measurements to estimates of ecosystem respiration made by scaling chamber measurements at six coniferous boreal sites. J. Geophys. Res. Atmos. 102 (D24), 28977-28985.

Law, B.E., Baldocchi, D.D., Anthoni, P.M., 1999. Below-canopy and soil $\mathrm{CO}_{2}$ fluxes in a ponderosa pine forest. Agric. Forest Meteorol. 94 (3-4), 171-188.

Law, B.E., et al., 2001a. Spatial and temporal variation in respiration in a young ponderosa pine forests during a summer drought. Agric. Forest Meteorol. 110 (1), 27-43.

Law, B.E., Thornton, P.E., Irvine, J., Anthoni, P.M., Van Tuyl, S., 2001b. Carbon storage and fluxes in ponderosa pine forests at different developmental stages. Global Change Biol. 7 (7), 755 777.
Lee, X., 2000. Air motion within and above forest vegetation in nonideal conditions. Forest Ecol. Manage. 135 (1-3), 3-18.

Lee, X., Black, T.A., 1993. Comparison of flux measurements with open- and closed-path gas analyzers above an agricultural field and forest floor. Boundary Layer Meteorol. 67, 195-202.

Lee, X.H., Shaw, R.H., Black, T.A., 1994. Modeling the effect of mean pressure-gradient on the mean flow within forests. Agric. Forest Meteorol. 68 (3-4), 201-212.

Lee, Y.H., Mahrt, L., 2005. Effect of stability on mixing in open canopies. Agric. Forest Meteorol. 135 (1-4), 169-179.

Mahrt, L., Lee, X.H., Black, A., Neumann, H., Staebler, R.M., 2000. Nocturnal mixing in a forest subcanopy. Agric. Forest Meteorol. 101 (1), 67-78.

Meyers, T.P., Paw U, K.T., 1986. Testing of a higher order closure model for modeling airflow within and above plant canopies. Boundary Layer Meteorol. 37, 297-311.

Middleton, E.M., et al., 1997. Seasonal variability in foliar characteristics and physiology for boreal forest species at the five Saskatchewan tower sites during the 1994 Boreal EcosystemAtmosphere Study. J. Geophys. Res. Atmos. 102 (D24) 28831-28844.

Misson, L., et al., 2006a. Influences of canopy photosynthesis and summer rain pulses on root dynamics and soil respiration in a young ponderosa pine forest. Tree Physiol. 26 (7), 833844.

Misson, L., Tu, K.P., Boniello, R.A., Goldstein, A.H., 2006b. Seasonality of photosynthetic parameters in a multi-specific and vertically complex forest ecosystem in the Sierra Nevada of California. Tree Physiol. 26 (6), 729-741.

Moren, A.S., Lindroth, A., 2000. $\mathrm{CO}_{2}$ exchange at the floor of a boreal forest. Agric. Forest Meteorol. 101 (1), 1-14.

Nunez, M., Bowman, D., 1986. Nocturnal cooling in a high-altitude stand of eucalyptus-delegatensis as related to stand density. Aust. Forest Res. 16 (2), 185-197.

Oliver, S.A., Oliver, H.R., Wallace, J.S., Roberts, A.M., 1987. Soil heat-flux and temperature-variation with vegetation, soil type and climate. Agric. Forest Meteorol. 39 (2-3), 257-269.

Pfitsch, W.A., Pearcy, R.W., 1989. Daily carbon gain by adenocaulonbicolor (Asteraceae), a Redwood Forest Understory Herb, in relation to its light environment. Oecologia 80 (4), 465-470.

Pinker, R.T., Holland, J.Z., 1988. Turbulence structure of a tropical forest. Boundary Layer Meteorol. 43 (1-2), 43-63.

Pyles, R.D., Kyaw, T.P.U., Falk, M., 2004. Directional wind shear within an old-growth temperate rainforest: observations and model results. Agric. Forest Meteorol. 125 (1-2), 19-31.

Raupach, M.R., Thom, A.S., 1981. Turbulence in and above plant canopies. Ann. Rev. Fluid Mech. 13, 97-129.

Raupach, M.R., 1987. Canopy transport processes. In: Steffen, W.L., Denmead, O.T. (Eds.), Flow and Transport in the Natural Environment: Advances and Applications, pp. 95-127.

Reich, P.B., et al., 2003. The evolution of plant functional variation: traits, spectra, and strategies. Int. J. Plant Sci. 164 (3), S143S164.

Reichstein, M., et al., 2003. Modeling temporal and large-scale spatial variability of soil respiration from soil water availability, temperature and vegetation productivity indices. Global Biogeochem. Cycles 17 (4).

Rovira, A.D., 1953. Use of the Warburg apparatus in soil metabolism studies. Nature 172 (4366), 29-30.

Ross, J., 1975. Radiative transfer in plant communities. In: Monteith, J.L. (Ed.), Vegetation and the Atmosphere, vol. 1, Principles. Academic Press, NY, pp. 13-55. 
Schlesinger, W.H., Andrews, J.A., 2000. Soil respiration and the global carbon cycle. Biogeochemistry 48 (1), 7-20.

Scott, R.L., et al., 2003. The understory and overstory partitioning of energy and water fluxes in an open canopy, semiarid woodland. Agric. Forest Meteorol. 114 (3-4), 127-139.

Shinn, J.H., 1971. Spiral vertical variation of wind in forests. Bull. Am. Meteorol. Soc. 52 (4), 308-316.

Shuttleworth, W.J., et al., 1984. Observations of radiation exchange above and below Amazonian forest. Quart. J. R. Meteorol. Soc. 110 (466), 1163-1169.

Smith, F., Carson, D., Oliver, H., 1972. Mean wind direction shear through a forest canopy. Boundary Layer Meteorol. 3, 178190.

Staebler, R.M., Fitzjarrald, D.R., 2005. Measuring canopy structure and the kinematics of subcanopy flows in two forests. J. Appl. Meteorol. 44 (8), 1161-1179.

Subke, J.A., Tenhunen, J.D., 2004. Direct measurements of $\mathrm{CO}_{2}$ flux below a spruce forest canopy. Agric. Forest Meteorol. 126 (1-2), 157-168.

Tang, J.W., Baldocchi, D.D., Xu, L., 2005. Tree photosynthesis modulates soil respiration on a diurnal time scale. Global Change Biol. 11 (8), 1298-1304.

Thom, A.S., 1975. Momentum, mass and hear exchange of plant communities. In: Monteith, J.L. (Ed.), Vegetation and the Atmosphere, vol. 1, Principles. Academic Press, NY, pp. 57-109.

Trumbore, S., 2000. Age of soil organic matter and soil respiration: radiocarbon constraints on belowground C dynamics. Ecol. Appl. 10 (2), 399-411.

Valentini, R., et al., 2000. Respiration as the main determinant of carbon balance in European forests. Nature 404 (6780), 861-865.
Vose, J.M., Sullivan, N.H., Clinton, B.D., Bolstad, P.V., 1995. Vertical leaf-area distribution, light transmittance, and application of the Beer-Lambert Law in 4 mature Hardwood Stands in the Southern Appalachians. Can. J. Forest Res.-Revue Canadienne De Recherche Forestiere 25 (6), 1036-1043.

Wedler, M., Geyer, R., Heindl, B., Hahn, S., Tenhunen, J.D., 1996. Leaf-level gas exchange and scaling-up of forest understory carbon fixation rates with a "patch-scale" canopy model. Theor. Appl. Climatol. 53 (1-3), 145-156.

Wilson, K.B., Hanson, P.J., Baldocchi, D.D., 2000. Factors controlling evaporation and energy partitioning beneath a deciduous forest over an annual cycle. Agric. Forest Meteorol. 102 (2-3), 83-103.

Wilson, K.B., Meyers, T.P., 2001. The spatial variability of energy and carbon dioxide fluxes at the floor of a deciduous forest. Boundary Layer Meteorol. 98 (3), 443-473.

Xu, M., DeBiase, T.A., Qi, Y., Goldstein, A., Liu, Z.G., 2001. Ecosystem respiration in a young ponderosa pine plantation in the Sierra Nevada Mountains, California. Tree Physiol. 21 (5), 309-318.

Yang, P.C., Black, T.A., Neumann, H.H., Novak, M.D., Blanken, P.D., 1999. Spatial and temporal variability of $\mathrm{CO}_{2}$ concentration and flux in a Boreal Aspen forest. J. Geophys. Res. Atmos. 104 (D22), 27653-27661.

Zhang, W., et al., 2005. Soil microbial responses to experimental warming and clipping in a tallgrass prairie. Global Change Biol. 11 (2), 266-277.

Zogg, G.P., et al., 1997. Compositional and functional shifts in microbial communities due to soil warming. Soil Sci. Soc. Am. J. 61 (2), 475-481. 